God Said to Abraham/Kill Me a Son: Why the Insanity Defense and the Incompetency Status Are Compatible with and Required by the Convention on the Rights of Persons with Disabilities and Basic Principles of Therapeutic Jurisprudence

Michael L. Perlin

New YorkLaw School, michael.perlin@nyls.edu

Follow this and additional works at: http://digitalcommons.nyls.edu/fac_articles_chapters Part of the Criminal Law Commons, Disability Law Commons, Health Law and Policy Commons, Human Rights Law Commons, Jurisprudence Commons, and the Law and Psychology Commons

Recommended Citation

54 Am. Crim. L. Rev. 477 (2017)

This Article is brought to you for free and open access by the Faculty Scholarship at DigitalCommons@NYLS. It has been accepted for inclusion in Articles \& Chapters by an authorized administrator of DigitalCommons@NYLS. 


\section{"GOD SAID TO ABRAHAM/KILL ME A SON": WHY THE INSANITY DEFENSE AND THE INCOMPETENCY STATUS ARE COMPATIBLE WITH AND REQUIRED BY THE CONVENTION ON THE RIGHTS OF PERSONS WITH DISABILITIES AND BASIC PRINCIPLES OF THERAPEUTIC JURISPRUDENCE}

Michael L. Perlin, Esq.*

\section{INTRODUCTION}

The conditions of treatment of forensic patients - their institutionalization in psychiatric facilities, their confinement in such facilities, and their possible pathways out - has always been stunningly under-considered, not just in academic literature and case law, but also in the discussions and negotiations that led to the final draft of the Convention on the Rights of Persons with Disabilities ("CRPD"). In an important book written about the "back story" of the negotiations, the role of Non-Governmental Organizations ("NGO"), and the back-and-forth that led to the CRPD's promulgation, there is virtually no mention of the specific and unique issues that are raised by the institutionalization of forensic patients. ${ }^{2}$ Nor is there any mention whatsoever of the multiple routes that lead to individuals' entering such facilities - some because they are currently seen as incompetent to stand trial, some because they have been deemed permanently incompetent to stand trial, some because they are being evaluated after having filed notice of seeking to plead the insanity defense, some because they have been found not guilty by reason of insanity, and, in some nations, some because they have been transferred after conviction from prisons. ${ }^{3}$

\footnotetext{
* Professor Emeritus of Law; Founding Director, International Mental Disability Law Reform Project, New York Law School; and Co-Founder, Mental Disability Law and Policy Associates. An earlier version of this Article was presented as a keynote address to the fourth international therapeutic jurisprudence conference at the University of Auckland, NZ, on September 4, 2015. I wish to thank Chris Slobogin, Eleanore Fritze, Douglas Mossman, Henry Dlugacz, David Wexler, Shelley Kierstead, Maya Sabatello, Debbie Dorfman, Heather Ellis Cucolo, Mehgan Gallagher, Ken Gallant, and Penny Weller for their insightful and helpful comments and suggestions. I am particularly indebted to Eleanore for sharing so many Australian source documents with me. I also wish to thank Katey Thom and Warren Brookbanks for inviting me to present a version of this Article as one of the keynotes at the University of Auckland conference. (C) 2017, Michael L. Perlin.

1. Convention on the Rights of Persons with Disabilities, G.A. Res. 61/106 (Dec. 6, 2006) [hereinafter CRPD].

2. See Human Rights and Disability Advocacy (Maya Sabatello \& Marianne Schulze eds., 2014); see also Maya Sabatello, Where Have the Rights of Forensic Patients Gone?, 109 AM. Soc'Y INT'L L. Proc. 77, 78 (2015) ("[F]orensic patients ... remained largely invisible throughout the drafting process.").

3. See generally 3 Michael L. Perlin \& Heather Eldis Cucolo, Mental Disablity law: Civil and Criminal \$\$ 13-1 to 14-3 (3d ed. 2016).
} 
In an earlier book chapter that I wrote with Meredith Schriver, ${ }^{4}$ we argued that most of the case law that had developed about institutionalized persons "ignores forensic patients entirely," and noted that "[e]ven in this hidden world of those institutionalized because of psychiatric disability (or alleged disability), forensic patients ... remain the most hidden." Schriver and I also alleged that there was virtually no significant opposition to this extra level of social isolation.

It was "just fine with most of those who had been involved in the patients' rights revolution that has restructured mental health care around the world." It was "fine to the advocacy groups that came forward at this time, since the existence of a forensic 'world' could be used as evidence that there was a causal relationship between mental illness (or intellectual disability) and "dangerousness." ", It was also "just fine" to the "lawyers who brought the bulk of the first generation of public interest cases since one of the significant underpinnings of the initial right to liberty/least restrictive alternative civil rights suits was that the plaintiff had never been "alleged to have committed any crime,", and to the "state hospital system, since it was clear that if it appeared that this population was being released or

4. Michael L. Perlin \& Meredith R. Schriver, "You that Hide Behind Walls": The Relationship Between the Convention on the Rights of Persons with Disabilities and the Convention Against Torture and the Treatment of Institutionalized Forensic Patients, in Ctr. For Human Rights \& Humanitarian Law, Am. Univ. Washington Coll. of Law, Torture in Healthcare Settings: Reflections on the Special Rapporteur on Torture's 2013 Thematic Report 195 (2013); see also Michael L. Perlin, International Human Rights and Institutional Forensic Psychiatry: The Core Issues, in The Use of Coercive Measures in Forensic Psychlatric Care: Legal, Ethical and Practical Challenges 9 (Birgit Völlm \& Norbert Nedopil eds., 2016) [hereinafter Perlin, The Core Issues] (noting that forensic patients have traditionally been hidden from public view, the legal system, and the mental-health system).

5. Perlin \& Schriver, supra note 4, at 197. This is not an issue limited to the United States. On the disregard for the dignity of forensic patients in Austria, see, for example, Independent Monitoring Committee for the Implementation of the U.N. Convention on the Rights of Persons with Disabilities, Forensic CommitmentStatement on the Current Situation and Prevention at 4-5 (Jan. 19, 2015) (discussing "a disregard for dignity"). Paradoxically, this comes at a time at which the numbers of forensic patients are increasing. See, e.g., William $\mathrm{H}$. Fisher, Jeffrey L. Geller \& John A. Pandiani, The Changing Role of the State Psychiatric Hospital, 28 HeALTH AfF. 676, 679 (2009); Claire Marie Hagan, Sheltering Psychiatric Patients from the DeShaney Storm: A Proposed Analysis for Determining Affirmative Duties to Voluntary Patients, 70 WASH. \& LEE L. REv. 725, 756 (2013) ("State hospitals are also devoting more beds to forensic patients who come from the criminal system." (citing Substance Abuse \& Mental Health Servs. Admin., U.S. Dep’t of Health \& Human Servys., Funding and Characteristics of State Mental Health Agencies, 2009 at 71 (2009) ("Since 1993, state psychiatric hospital expenditures have increasingly been applied to forensic services, jumping from 10.7 percent of total state psychiatric hospital expenditures in 1993 to 26 percent in 2007."))). Numbers of forensic patients are increasing not just in the United States, but also in other nations. See, e.g., Sheilagh Hodgins, Rüdiger Müller-Isberner \& Jean-François Allaire, Attempting to Understand the Increase in the Numbers of Forensic Beds in Europe: A Multi-Site Study of Patients in Forensic and General Psychiatric Services, 5 InT'L J. Forensic Mental Health 173, 173 (2006).

6. Perlin, The Core Issues, supra note 4, at 11.

7. Id. This relationship has often been extraordinarily strained. See, e.g., Michael L. Perlin, "Half-Wracked Prejudice Leaped Forth": Sanism, Pretextuality, and Why and How Mental Disability Law Developed as It Did, 10 J. CONTEMP. Legal Issues 3,30 n. 158 (1999).

8. Perlin, The Core Issues, supra note 4, at 11 (citing Lessard v. Schmidt, 349 F. Supp. 1078, 1096 (E.D. Wis. 1972)). 
deinstitutionalized, there would be a predictable public outcry." Importantly, it was also "just fine" to "prosecutors and police officials since it insured that this population would remain locked up indefinitely, as it always had been." ${ }^{10}$ As a result of all of this, the status quo remained for about forty years, and the "patients' rights revolution" has had very little impact on those in forensic facilities. ${ }^{11}$

I believe that this is still true, but I fear that, paradoxically, instead of things getting better in the future, they may get far worse if the General Comments ("GC") to Articles 12 and 14 of the CRPD are to gain traction, ${ }^{12}$ and if those Comments lead to the abolition of the insanity defense or the incompetency status. The GCs unequivocally state that "declarations of unfitness to stand trial and the detention of persons based on that declaration" violate Article $14,{ }^{13}$ and that "recognition of the legal capacity of persons with disabilities requires abolishing a defence based on the negation of criminal responsibility because of the existence of a mental or intellectual disability." ${ }^{14}$ Such policy pronouncements of U.N. treaty bodies, in the form of GCs or recommendations, are not considered binding international law, but are often viewed as "helpful interpretations of the treaty at issue from recognized authorities, which can guide national policies in a rightsaffirming direction." 15

9. Id. (citing Raymond A. Lemay, Deinstitutionalization of People with Developmental Disabilities: A Review of the Literature, 28 CAN. J. COMmUnity Mental Health 181, 181 (2009)).

10. Id. When I was a deputy public defender in New Jersey, I filed a class-action suit, Dixon v. Cahill, which resulted in a ruling that the indefinite incarceration of individuals in the Vroom Building, New Jersey's maximum-security facility for the "criminally insane," violated Jackson, and that individual hearings were warranted for each inmate. Dixon v. Cahill, No. L30977/y-71 P.W. (N.J. Super. Ct. Law Div. 1973), reprinted in PerLin \& Cucolo, supra note 3, \$ 19-8; see also Michael L. Perlin, "For the Misdemeanor Outlaw": The Impact of the ADA on the Institutionalization of Criminal Defendants with Mental Disabilities, 52 ALA. L. REV. 193, 206-07, 207 n.94 (2000) [hereinafter Perlin, Misdemeanor Outlaw] (discussing Dixon v. Cahill and applying Due Process Clause to incompetent-to-stand-trial defendants). The courts ultimately found that 185 of the 225 patients in that facility were illegally detained. See Michael L. Perlin, "May You Stay Forever Young": Robert Sadoff and the History of Mental Disability Law, 33 J. AM. ACAD. Psychiatry \& L. 236, 236-37 (2005).

11. See Perlin \& Schriver, supra note 4, at 197-98.

12. See infra text accompanying notes 124-57. See also Andrew Wolman, Abortion in Korea: A Human Rights Perspective on the Current Debate over Enforcement of the Laws Prohibiting Abortion, 9 J. INT'L Bus. \& L. 153, 163 (2010) (citing Kerstin Mechlem, Treaty Bodies and the Interpretation of Human Rights, 42 VAND. J. Transnat'L L. 905, 924 (2009)); see also, e.g., Michael O'Flaherty, The Concluding Observations of United Nations Human Rights Treaty Bodies, 6 Hum. RTs. L. Rev. 27, 33 (2006).

13. Comm. on the Rights of Persons with Disabilities, Statement on Article 14 of the Convention on the Rights of Persons with Disabilities (Sept. 2014) [hereinafter CRPD, Statement on Article 14], http://www.ohchr.org/EN/ NewsEvents/Pages/DisplayNews.aspx?NewsID $=15183 \&$ LangID $=$ E. The Committee has also criticized individual governments for maintaining procedures that permit a defendant to be deemed "unfit" to stand trial and subsequently detained. See, e.g., Comm. on the Rights of Persons with Disabilities, Concluding Observations on the Initial Report of New Zealand II 33, CRPD/C/NZL/CO/1 (Oct. 31, 2014).

14. U.N. Human Rights Council, Thematic Study by the United Nation High Commissioner for Human Rights on Enhancing Awareness and Understanding of the Convention on the Rights of Persons with Disabilities, II 47 , U.N. Doc. A/HRC/10/48, at 15 (Jan. 26, 2009), http://www.un.org/disabilities/documents/reports/ohchr/A.HRC. 10.48AEV.pdf.

15. Wolman, supra note 12, at 163 (citing Mechlem, supra note 12, at 924). 
These Comments have been embraced by some members of the disability-rights community, ${ }^{16}$ and the abolitionist movement is growing. ${ }^{17}$ This position is wrongheaded in every possible way. If adopted, it will make a mockery of any modicum of fair-trial rights for the population in question, and will likely lead to torture of this population in the jails and prisons in which it will languish. ${ }^{18}$ The statement in the GCs - "that declarations of unfitness to stand trial and the detention of persons based on that declaration is contrary to article 14 of the [CRPD] since it deprives the person of his or her right to due process and safeguards that are applicable to every defendant" 19 - is the single most wrongheaded (and potentially destructive) statement uttered by any supporter of the CRPD since its initial drafting. ${ }^{20}$ The abolition of this status will further enhance the likelihood that morally and

16. See, e.g., Tina Minkowitz, Some Thoughts on Insanity Defense, MAD IN AM. (July 12, 2014) [hereinafter Minkowitz, Some Thoughts], http://www.madinamerica.com/2014/07/thoughts-insanity-defense/; Tina Minkowitz, Rethinking Criminal Responsibility from a Critical Disability Perspective: The Abolition of Insanity/ Incapacity Acquittals and Unfitness to Plead, and Beyond, 23 GRIFFITH L. REV. 434 (2014) [hereinafter Minkowitz, Rethinking Criminal Responsibility]; World Network of Users and Survivors of Psychiatry, Implementation Manual for the United Nations Convention on the Rights of Persons with Disabilities (2008), http://www.un.org/disabilities/documents/COP/WNUSP\%20CRPD\%20Manual.doc.

17. See Charles O'Mahony, Impact of Human Rights Approach in Member States'Legislation: Legal Capacity in Ireland, ec.europa.eu/social/BlobServlet?docId=15773\&langId=en.

18. See infra text accompanying notes $205-08$ (noting that persons with mental disabilities are regularly brutalized and tortured in prison settings).

19. CRPD, Statement on Article 14, supra note 13.

20. Before I became a professor, I spent thirteen years as a lawyer representing persons with mental disabilities, including three years during which my focus was primarily on such individuals charged with crimes. In this role, when I was deputy public defender in Mercer County (Trenton), New Jersey, I represented several hundred individuals at New Jersey's "maximum security hospital for the criminally insane," both in individual cases and in a class action, Dixon v. Cahill, which implemented the then-recent U.S. Supreme Court case of Jackson v. Indiana, 406 U.S. 715 (1972). See supra note 10. Jackson had declared unconstitutional a state policy that allowed for the indefinite commitment of a pretrial detainee in maximum-security forensic facilities if it was unlikely that he would regain his capacity to stand trial in the "foreseeable future."

I continued to represent this population for a decade in my later positions as director of the New Jersey Division of Mental Health Advocacy and Special Counsel to the New Jersey Public Advocate. Also, as a public defender, I represented, at trial, many defendants who were incompetent to stand trial and others who, although competent, pleaded not guilty by reason of insanity. See generally, e.g., Michael L. Perlin, Mental Patient Advocacy by a Public Advocate, 54 Psychiatric Q. 169 (1982). Finally, during the time that I directed the Federal Litigation Clinic at New York Law School, I filed a brief on behalf of appellant (amicus Committee on the Fundamental Rights and Equality of Ex-Patients) in Ake v. Oklahoma, 470 U.S. 68 (1985) (finding right of indigent defendant to independent psychiatrist to aid in presentation of insanity defense).

These experiences gave me, I think, a unique perspective on the issues at hand. There is no question that the conditions in which these individuals were housed were horrific - they shocked the conscience and were about as counter-therapeutic as one could imagine. But to think that the best remedy was to abolish the only realistic hope they had to avoid the even-more-brutal conditions of state prison is, to me, bizarre. It is even more bizarre since, to the best of my knowledge, none of the commentary that I discuss in this paper even considers the reality that raising the incompetency status is in no way a concession of factual guilt. See Michael L. Perlin, "Everything's a Little Upside Down, as a Matter of Fact the Wheels Have Stopped": The Fraudulence of the Incompetency Evaluation Process, 4 Hous. J. Health L. \& PoL'y 239, 246 (2004) [hereinafter Perlin, Upside Down] (“Although there is nothing in the invocation of the incompetency status that at all concedes factual guilt . . it is assumed by all that the defendant did, in fact, commit the crime."). 
factually innocent people will be convicted and imprisoned, ${ }^{21}$ likely for far longer than persons without mental disabilities for like offenses. ${ }^{22}$ Also, factually guilty defendants will be robbed of their opportunities to make important choices such as choosing to knowingly, voluntarily, and intelligently enter into a plea bargain. ${ }^{23}$

This Article argues that the interpretations of the GCs ignore the rest of the CRPD and other prevailing international human-rights law, make no theoretical or conceptual sense, disregard the history of how society has treated persons with serious mental disabilities who are charged with crimes, and will lead to torture of this population in prison, at the hands of both prison guards and other prisoners. This position also contradicts every precept of therapeutic jurisprudence ("TJ") ${ }^{24}$

In his thoughtful piece that seeks to integrate the traditional insanity-defense standards with other criminal-law defenses like mistake of fact or duress, Professor Christopher Slobogin notes how “[ $t]$ he category of 'criminal insanity' perpetuates the extremely damaging myth that people with mental disability are especially dangerous or especially lacking in self-control." ${ }^{25}$ He cites an article I wrote about

21. See infra text accompanying note 75 (noting that incompetency is a status, not a defense, and that raising it is in no way a concession of factual guilt).

22. See Michael L. Perlin, The Jurisprudence of the Insanity Defense 109 (1994) [hereinafter Perlin, InSAnity Defense Jurisprudence] (citing Jeraldine Braff, Thomas Arvanites \& Henry J. Steadman, Detention Patterns of Successful and Unsuccessful Insanity Defendants, 21 CRIMINOLOGY 439, 445 (1983) (stating that unsuccessful insanity pleaders were institutionalized $22 \%$ longer than those who never raised the plea)) (discussing how defendants who unsuccessfully pleaded insanity - thus raising their mental-health status to the fact finder-served significantly longer sentences than defendants convicted of like charges who did not proffer an insanity defense); see also David C. Baldus et Al., Equal Justice and the Death Penalty: A Legal and EMPIRICAL ANALYSIS 644-45 (1990) (stating that research into 128 Georgia capital cases in 1990 revealed that an unsuccessful insanity defense strongly correlated with a sentence of death). Such an unsuccessful defense may also thwart a defendant's attempts to seek sentencing reduction under the Federal Sentencing Guidelines. See James Gusfa \& Maya Prabhu, Sentencing Adjustment Following an Unsuccessful Insanity Defense, 43 J. AM. ACAD. PSychlatRY \& L. 114 (2015) (discussing United States v. Herriman, 739 F.3d 1250 (10th Cir. 2014)).

23. If a defendant is incompetent to stand trial - as that term has been used for millennia, see PERLIN \& Cucolo, supra note 3, § 13-1.2 to 13-1.2.2 - then he does not have the "sufficient present ability to consult with his lawyer with a reasonable degree of rational understanding [or] a rational as well as factual understanding of the proceedings against him." See Dusky v. United States, 362 U.S. 402, 402 (1960) (per curiam); infra text accompanying note 128 .

24. For an extensive discussion on TJ, see infra text accompanying notes 237-47. TJ "asks us to look at law as it actually impacts people's lives" and "focus[es] on law's impact on emotional life" and psychological well-being. Bruce J. Winick, Foreword: Therapeutic Jurisprudence Perspectives on Dealing with Victims of Crime, 33 Nova L. Rev. 535, 535 (2009); see David B. Wexler, Practicing Therapeutic Jurisprudence: Psycholegal Soft Spots and Strategies, in Dennis P. Stolle et al., Practicing Therapeutic Jurisprudence: Law AS A HELPING PROFESSION 45 (2000). Its ultimate aim is to determine whether legal rules, procedures, and roles for lawyers can or should be reshaped to enhance their therapeutic potential while not subordinating due-process principles. See, e.g., Michael L. Perlin, "And My Best Friend, My Doctor/Won't Even Say What It Is I've Got": The Role and Significance of Counsel in Right to Refuse Treatment Cases, 42 SAN DIEGo L. REv. 735, 751 (2005) [hereinafter Perlin, Role and Significance of Counsel].

25. Christopher Slobogin, Eliminating Mental Disability as a Legal Criterion in Deprivation of Liberty Cases: The Impact of the Convention on the Rights of Persons with Disabilities on the Insanity Defense, Civil Commitment, and Competency Law, 40 LAW \& PSYCHOL. Rev. 297, 309 (2016) [hereinafter Slobogin, Eliminating Mental Disability]. I agree with Slobogin that the entire way the insanity defense is perceived and discussed in the public arena perpetuates these sanist myths. I believe it is not the defense but rather the empirically - and 
what I call "sanism":26 "the pervasive stigma that befalls persons with mental disabilities." 27 I agree that sanism leads many to believe that insanity pleaders are somehow typical of all persons with mental disabilities. But, as I discuss extensively below, that same sanism will lead to disaster for this population if this status and defense are abolished. ${ }^{28}$

Support of the abolitionist positions by portions of the disability-rightsadvocacy community exhibits a startling lack of understanding of the treatment of this population in prison settings. By obsessively focusing on only two articles of the CRPD, the abolitionist position ignores other articles of that CRPD that support the continuation of this defense and this status, ${ }^{29}$ as well as other international human-rights conventions that speak to the right to a "fair trial." 30 Even if, under a tortured reading, one can assume that Article 12 can be read to support this position, consideration of it in the context of the rest of the Convention must lead us to reject this argument. The abolitionist position is shortsighted and, if adopted, would inevitably lead to a worsening of the lives of a segment of the population of persons with disabilities that has never been consulted in this conversation. ${ }^{31}$ For example, Article 4(4) of the CRPD mandates that "[n]othing in the present Convention shall affect any provisions which are more conducive to the realization of the rights of persons with disabilities and which may be contained in the law of a State Party or international law in force for that State." 32 There is no

behaviorally-inaccurate myths that surround the conversation about the defense. See Michael L. Perlin, The Insanity Defense: Nine Myths that Will Not Go Away, in The InSANity Defense: Multwisciplinary Views On ITS History, Trends, AND Controversies 3 (Mark D. White ed., 2017) [hereinafter Perlin, Nine Myths].

26. Michael L. Perlin, On "Sanism," 46 SMU L. Rev. 373, 374 (1992).

27. Michael L. Perlin, "Striking for the Guardians and Protectors of the Mind": The Convention on the Rights of Persons with Mental Disabilities and the Future of Guardianship Law, 117 PENN ST. L. REv. 1159, 1161 (2013) [hereinafter Perlin, Guardians and Protectors] (quoting Michael L. Perlin, International Human Rights and Mental Disability Law: When the Silenced Are Heard viii (2012) [hereinafter Perlin, When the Silenced ARE HEARD]).

28. See infra note 92 (discussing, in a parallel context, Justice Scalia's dissent in Indiana v. Edwards, 554 U.S. 164 (2008) (finding that defendant who is competent to stand trial may not be competent to represent himself)).

29. See infra text accompanying notes 50-53.

30. See infra text accompanying notes 54-55.

31. My argument is strengthened by a consideration of the "incredible dilemma" literature, which seeks to resolve the knotty dilemma of harmonizing constitutional and statutory rights that appear to be in direct conflict. On the significance of this dilemma in other areas of mental-disability law, see, for example, Paul S. Appelbaum, Protecting the Rights of Persons with Disabilities: An International Convention and Its Problems, 67 PSYCHIATRIC SERvs. 366, 367 (2016) ("That [abolition] would lead to the conviction and imprisonment of defendants with severe mental illnesses who would not previously have been held responsible for their actions goes unmentioned."); Michael L. Perlin, Hospitalized Patients and the Right to Sexual Interaction: Beyond the Last Frontier?, 20 N.Y.U. Rev. L. \& Soc. Change 517, 540 n.142 (1994) (citing Peter Westen, Incredible Dilemmas: Conditioning One Constitutional Right on the Forfeiture of Another, 66 Iowa L. REv. 741, 742 (1981)); see also infra note 53 .

32. CRPD, supra note 1, art. 4 (emphasis added). My thanks to Penny Weller for reminding me of this provision. See also John Dawson, A Realistic Approach to Assessing Mental Health Laws' Compliance with the UNCRPD, 40 INT'L J.L. \& PSYCHIATRY 70, 71 (2015) (arguing that failure to consider a person's disability may, under some circumstances, be discriminatory). 
mention of Article 4 in any of the literature that suggests that the CRPD requires the abolition of the insanity defense, the incompetency status, or both.

Finally, this proposal repudiates every tenet of TJ. Abolishing the incompetency status and the insanity defense deprives this population of authentic due process, participating in fair trials, and having a voice. ${ }^{33}$ It may or may not be coincidental that one of the leaders of the CRPD-based movement to abolish these defenses is also on record as saying that TJ "is a concept to avoid." 34 This position must be rejected. $^{35}$

First, this Article will discuss the significance of the CRPD and why, when it is read as an integrated document, the interpretations in the GCs and the supporting literature must be unequivocally rejected.

Next, this Article will consider the singular role of the insanity defense and incompetency status in legal history. Here, this Article acknowledges that, while pleading insanity may sometimes be a bad option, it is still one that needs to be retained, and retention of the plea reinforces the reality that raising the incompetency status is not an admission of factual guilt. ${ }^{36}$ Thus, trying a person who is unable to cooperate with her counsel, rationally understand the proceedings against her, or both, makes it more likely that she will be convicted of crimes of which she may not be guilty, a base and basic violation of human decency.

This Article will then consider the GCs to Articles 12 and 14 that are at the center of this controversy, concluding that they make no conceptual sense. If implemented, they would violate due process, dignity, and fair-trial mandates, and would inevitably lead to the torture of persons with mental disabilities who are charged with and convicted of crimes. ${ }^{37}$ This denouement is even more staggering when we realize that there is no indication that this outcome was ever in the minds of the drafters or was ever debated, or that the populations in question were ever consulted. This latter failure frontally mocks the precept of "[n]othing about us, without us." 38

33. On the impact of recent defense and incompetency developments on the "pathways" of persons with serious mental disabilities charged with crime in the context of "voice," see infra text accompanying notes 246-47; Michael L. Perlin, "Wisdom Is Thrown into Jail": Using Therapeutic Jurisprudence to Remediate the Criminalization of Persons with Mental Illness, 17 Mich. ST. U. J. MED. \& L. 343, 364 (2013).

34. Minkowitz, Some Thoughts, supra note 16.

35. See infra text accompanying notes $246-68$.

36. This contrasts with the insanity defense, which is a concession that the defendant committed the actus reus. See Jones v. United States, 463 U.S. 354, 363 (1983) ("A verdict of not guilty by reason of insanity establishes two facts: (i) the defendant committed an act that constitutes a criminal offense, and (ii) he committed the act because of mental illness.").

37. On the question of how treatment of persons with mental disabilities in healthcare facilities may sometimes amount to torture under international human-rights law, see Bernadette McSherry \& Piers Gooding, Torture and Ill-Treatment in Health Care Settings: Lessons from the United Nations, 20 J.L. \& MED. 712, 712 (2013).

38. Michael L. Perlin, "A Change Is Gonna Come": The Implications of the United Nations Convention on the Rights of Persons with Disabilities for the Domestic Practice of Constitutional Mental Disability Law, 29 N. ILL. U. L. REv. 483, 489 (2009) (referring to this as the "clarion cry" of the disability-rights movement). 
Finally, the abolition of the insanity defense and incompetency status violates every precept of TJ. ${ }^{39}$ TJ sees three values as essential elements of the legal process: voice, validation, and voluntariness. ${ }^{40}$ Elimination of the insanity defense and incompetency status makes it virtually impossible that these values will be privileged, and makes it more likely that sanist behavior on the part of jails, prison administrators, and line staff will fester to an even greater extent than it does now.

The title of this Article comes from Bob Dylan's brilliant song, Highway 61 Revisited. ${ }^{41}$ I use it here because one of the most nettlesome subsets of insanitydefense cases flows from what are called "deific decree" cases, where an individual's psychotic delusion leads to a belief that he or she is acting under the direct command of God. ${ }^{42}$ Consider the full verse, and update it to current times:

Oh God said to Abraham, "Kill me a son"

Abe says, "Man, you must be puttin' me on"

God say, "No." Abe say, "What?"

God say, "You can do what you want Abe, but

The next time you see me comin' you better run"

Well Abe says, "Where do you want this killin' done?"

God says, "Out on Highway 61."43

Highway 61 Revisited is one of Dylan's most famous songs, and a standard interpretation is that it asks the question: "What kind of a person would it take to make the leap of faith required to murder one's own son at the command of one's God?" 44 That question can logically lead to an inquiry into the sanity of one who follows such a command to kill one's child. ${ }^{45}$ But another analysis, in a blog post by Dr. Ezra Cappell, Associate Professor of English and director of the InterAmerican Jewish Studies Program at the University of Texas at El Paso, sees a far

39. See Perlin, Role and Significance of Counsel, supra note 24, at 751; see also Michael L. Perlin, "Everybody Is Making Love/Or Else Expecting Rain": Considering the Sexual Autonomy Rights of Persons Institutionalized Because of Mental Disability in Forensic Hospitals and in Asia, 83 WASH. L. REV. 481, 510 (2008) [hereinafter Perlin, Sexual Autonomy]; Michael L. Perlin, "You Have Discussed Lepers and Crooks": Sanism in Clinical Teaching, 9 CliniCAL L. REv. 683, 711 n.164 (2003).

40. See, e.g., Amy D. Ronner, The Learned-Helpless Lawyer: Clinical Legal Education and Therapeutic Jurisprudence as Antidotes to Bartleby Syndrome, 24 Touro L. REV. 601, 627 (2008).

41. Oliver Trager, Keys to the Rain: The Definitive Bob Dylan Encyclopedia 252 (2004) (characterizing the song as "overflowing with genius"); Michael GRAY, THE BoB DYLAN ENCYClOPEDIA 324 (2008) (characterizing the song as "revolutionary and stunning").

42. See, e.g., State v. Cameron, 674 P.2d 650, 654 (Wash. 1983) (en banc). At least one commentator has used the biblical story that inspired Dylan's song as a backdrop for an analysis of deific-decree cases in general. See Andrew J. Demko, Abraham's Deific Defense: Problems with Insanity, Faith, and Knowing Right from Wrong, 80 Notre Dame L. Rev. 1961, 1961 (2005). For a recent, thoughtful article that calls for the end of the deific decree and the simultaneous expansion of the insanity defense, see Rabia Belt, When God Demands Blood: Unusual Minds and the Troubled Juridical Ties of Religion, Madness, and Culpability, 69 U. Miami L. Rev. 755 (2015).

43. See Bob Dylan, Highway 61 Revisited, Bов DYLAN, http://www.bobdylan.com/us/songs/highway-61revisited (last visited Nov. 29, 2016).

44. Clinton Heylin, Revolution in the Air: The Songs of Bob Dylan 1957-1973 258 (2009).

45. See Demko, supra note 42, at 1961. 
darker meaning. ${ }^{46}$ To Professor Cappell, the song reflects "the indifference of authority figures to outright cruelty, sadism, and destruction by those in power." ${ }^{47}$ I fear that the alleged reform of insanity-defense abolition will precisely lead to more "cruelty, sadism and destruction."

\section{THE CRPD}

Several years ago, in an article concluding that the CRPD required a total overhaul of the guardianship laws of all nations, I argued that this Convention "radically changes the scope of international human rights law as it applies to all persons with disabilities, and in no area is this more significant than in the area of mental disability law." ${ }^{48}$ In that article, I described my vision of the CRPD:

The Convention ... "is regarded as having finally empowered the 'world's largest minority' to claim their rights, and to participate in international and national affairs on an equal basis with others who have achieved specific treaty recognition and protection." [It] is the most revolutionary international human rights document ever created that applies to persons with disabilities. [It] furthers the human rights approach to disability and recognizes the right of people with disabilities to equality in almost every aspect of life. It firmly endorses a social model of disability - a clear and direct repudiation of the medical model that traditionally was part-and-parcel of mental disability law. "The Convention responds to traditional models, situates disability within a social model framework, and sketches the full range of human rights that apply to all human beings, all with a particular application to the lives of persons with disabilities." It provides a framework for ensuring that mental health laws "fully recognize the rights of those with mental illness." There is no question that it has "ushered in a new era of disability rights policy." 49

\footnotetext{
46. See Ezra Cappell, Highway 61 Revisited Again, InST. FOR JEwISH IDEAS \& IDEALS, https://www.jewishideas. org/article/highway-61-revisited-again.

47. Id. For context on Genesis 22, the portion of the Bible that inspired this verse of Dylan's song, see Sarah Imhoff, Violence and Secrecy: On Masculinity and the Akedah, 42 SH'MA J. 17 (2011):

Biblical scholars explain that the story of the Akedah [Akedah is Hebrew for binding] marks a turning point from ancient Near Eastern cultural traditions that include human sacrifice to a strikingly illustrative polemic against human sacrifice. Do not sacrifice your son, God tells Abraham. But ironically, the very acts that mark this watershed cultural transition away from violence are violent in themselves.
}

It should also be noted that the Israelites at that time were familiar with mental illness. See 1 Samuel 21:11-16. My thanks to my friend Doug Mossman, and to Gershom Barnard, Rabbi Emeritus of Northern Hills Synagogue, Cincinnati, Ohio, for pointing this out to me.

48. Perlin, Guardians and Protectors, supra note 27, at 1163.

49. Id. at 1173-74 (footnotes omitted) (quoting Rosemary Kayess \& Phillip French, Out of Darkness into Light? Introducing the Convention on the Rights of Persons with Disabilities, 8 HuM. RTS. L. REV. 1, 4 n.17 (2008); Janet E. Lord \& Michael A. Stein, Social Rights and the Relational Value of the Rights to Participate in Sport, Recreation, and Play, 27 B.U. INT'L L.J. 249, 256 (2009); Bernadette McSherry, International Trends in Mental Health Laws: Introduction, 26 L. IN ConTEXT 1, 8 (2008); Paul Harpur, Time to Be Heard: How Advocates 
Importantly, the CRPD calls for "[r]espect for inherent dignity"; "50 "[f]reedom from torture or cruel, inhuman or degrading treatment or punishment"; "[f]reedom from exploitation, violence and abuse", 52 and protection of the "integrity of the person."53 These proscriptions and prescriptions build on prior documentsthe rights to a fair trial set out in the International Covenant on Civil and Political Rights $^{54}$ and in reports and documents by the interregional human-rights courts. ${ }^{55}$ Scholars have made persuasive arguments that these rights apply to trials of alleged international war criminals; ${ }^{56}$ it is unthinkable to make a persuasive argument that they do not apply to persons with mental disabilities. ${ }^{57}$

Can Use the Convention on the Rights of Persons with Disabilities to Drive Change, 45 VAL. U. L. REv. 1271, $1295(2011))$.

50. CRPD, supra note 1, art. 3(a).

51. Id. art. 15 .

52. Id. art. 16.

53. Id. art. 17. See generally Penelope Weller, And Then What?, Presentation at the Biennial Congress of the International Academy of Law and Mental Health (July 2015) (slide show on file with author).

54. International Covenant on Civil and Political Rights, 999 U.N.T.S. 171, 176 art. 14 [hereinafter ICCPR]; see Andrew B. Friedman, Transitional Justice and Local Ownership: A Framework for the Protection of Human Rights, 46 AKRON L. Rev. 727, 742 (2013) ("The right to a fair trial is expressly guaranteed in nearly every general international human rights document including the Universal Declaration of Human Rights ('UDHR'), the International Covenant on Civil and Political Rights ('ICCPR'), and others.").

55. See, e.g., Inter-Am. Comm'n on Human Rights, Org. of Am. States, Report on Terrorism and Human Rights EXECUTIVE SUMMARY II 18 (2002), http://www.cidh.org/terrorism/eng/exe.htm; American Convention on Human Rights, 9 I.L.M. 673, 678 art. 8.

56. See U.N. Comm'n on Human Rights, Rep. of the Indep. Expert on the Protection of Human Rights and Fundamental Freedoms While Countering Terrorism, gyl 13-35, 44-55, U.N. Doc. E/CN.4/2005/103, at 8-13, 16-19 (Feb. 7, 2005); e.g., David Aronofsky, International War Crimes \& Other Criminal Courts: Ten Recommendations for Where We Go from Here and How to Get There-Looking to a Permanent International Criminal Tribunal, 34 DENV. J. INT'L L. \& POL'y 17, 23 (2006) ("'A]ny international or national court created to try war criminals and other international human rights violators must 'establish itself as the preeminent defender of . . . the right of every accused to a fair trial according to the most exacting standards of due process required by contemporary international law." (alteration in original) (quoting Monroe Leigh, The Yugoslav Tribunal: Use of Unnamed Witnesses Against Accused, 90 AM. J. INT'L L. 235, 237 (1996))).

57. Although the United States has not yet ratified the CRPD, then-President Obama signed the Convention over five years ago. See Michelle Diament, Obama Urges Senate to Ratify Disability Treaty, DisABLITY ScooP (May 18, 2012), https://www.disabilityscoop.com/2012/05/18/obama-urges-senate-treaty/15654/. Under such circumstances, "a state's obligations under it are controlled by the Vienna Convention on the Law of Treaties ... which requires signatories 'to refrain from acts which would defeat [the Disability Convention's] object and purpose." In re Mark C.H., 906 N.Y.S.2d 419, 433 (Surr. Ct. 2010) (second alteration in original) (citing Vienna Convention on the Law of Treaties art. 18, May 23, 1969, 1155 U.N.T.S. 331); see Henry Dlugacz \& Christopher Wimmer, The Ethics of Representing Clients with Limited Competency in Guardianship Proceedings, 4 St. Louis U. J. Health L. \& PoL'y 331, 362-63 (2011); e.g., In re Guardianship of Dameris L., 956 N.Y.S.2d 848, 854 (Surr. Ct. 2012) (holding that substantive-due-process requirement to adhere to principal of least restrictive alternative applies to guardianships sought for mentally disabled persons); Mark C.H., 906 N.Y.S.2d at 435 (holding that due process requires that the guardianship appointment be subject to a requirement of periodic reporting and review). Domestic courts in New York have thus cited the CRPD approvingly in cases involving guardianship matters. In one such case, Surrogate Judge Kristin Booth Glen noted that the CRPD was "entitled to 'persuasive weight' in interpreting our own laws and constitutional protections." Dameris L., 956 N.Y.S.2d at 855. See generally Michael L. Perlin \& Meredith R. Schriver, "You Might Have Drugs at Your 
As I will discuss more extensively below, it demeans any notion of dignity-one of the foundational rights of the CRPD—to deprive persons with mental disabilities the right to plead insanity, or to force them to trial if they are not competent to consult with counsel or understand the proceedings against them. ${ }^{58}$ It also flies in the face of nearly seventy years of international human-rights law. ${ }^{59}$

\section{The InCOMPETENCy Status AND the InSANity Defense}

\section{A. Incompetency Status}

Few principles are as firmly embedded in criminal jurisprudence as the doctrine that an "incompetent" defendant may not be put to trial. ${ }^{60}$ The doctrine traces back to mid-seventeenth-century England, ${ }^{61}$ with commentators generally focusing on: (1) the incompetent defendant's inability to aid in his defense, ${ }^{62}$ (2) the parallels to the historic ban on trials in absentia, ${ }^{63}$ and (3) the parallels to the problems raised by defendants who refused to plead to the charges entered against them. ${ }^{64}$

The primary purpose of the incompetency status was to "safeguard the accuracy of adjudication." As early as 1899, a U.S. federal court of appeals held that it was "not 'due process of law' to subject an insane person to trial upon an indictment involving liberty or life." ${ }^{.66}$ Contemporaneously, the Tennessee Supreme Court

Command": Reconsidering the Forced Drugging of Incompetent Pre-Trial Detainees from the Perspectives of International Human Rights and Income Inequality, 8 ALB. Gov'T L. REv. 381, 387 (2015).

58. See infra text accompanying note 134.

59. For an overview of international human-rights law in the context of persons with mental disabilities, and the need to ensure dignity in all interactions with the legal system, see generally PerLIN, When the S山ENCED ARE HEARD, supra note 27.

60. See generally PERLIN \& CuCOLO, supra note 3, § 13-2.

61. See Bruce J. Winick \& Terry L. DeMeo, Competence to Stand Trial in Florida, 35 U. Mlami L. Rev. 31 , 32 n.2 (1980). See generally Grp. For the AdVANCEMEnt of Psychlatry, Misuse of Psychlatry in the Criminal Courts: Competency to Stand Trial 912-15 (1974); Henry Weihofen, Mental Disorder as a Criminal DEFENSE 428-30 (1954). Roesch and Golding have suggested that the same problems may have been present as early as the thirteenth century. Ronald RoESCH \& StePHEN L. Golding, COMPETENCY TO STAND TRial 10 (1980).

62. See, e.g., 4 William Blackstone, Commentaries *386 401; 1 Matthew Hale et al., The History of THE Pleas of THE CRown 434 (1847). See generally Richard J. Bonnie, The Competence of Criminal Defendants with Mental Retardation to Participate in Their Own Defense, 81 J. Crim. L. \& CRIMINOLOGY 419 (1990); Thomas Grisso, Five-Year Research Update (1986-1990): Evaluations for Competence to Stand Trial, 10 BEHAV. ScI. \& L. 353 (1992).

63. See, e.g., Caleb Foote, A Comment on Pre-Trial Commitment of Criminal Defendants, 108 U. PA. L. REv. 832, 834 (1960). This issue is discussed in People v. Berling, 251 P.2d 1017, 1024 (Cal. Dist. Ct. App. 1953).

64. Until the late eighteenth century, if the court concluded that a defendant was remaining "mute of malice," it could order him to be subjected to the practice of peine forte et dure, the placing of increasingly heavy weights on the defendant's chest to "press" him for an answer. See, e.g., Ralph Slovenko, The Developing Law on Competency to Stand Trial, 5 J. PSYCHIATRY \& L. 165, 168-69 (1977). This practice was abolished in England in 1772. Id. at 168 .

65. Claudine Walker Ausness, Note, The Identification of Incompetent Defendants: Separating Those Unfit for Adversary Combat from Those Who Are Fit, 66 KY. L.J. 666, 668 (1978).

66. Youtsey v. United States, 97 F. 937, 941 (6th Cir. 1899). The constant blurring of the terms "insanity" and "incompetency" has been vexing. See, e.g., Bruce v. Estelle, 483 F.2d 1031, 1041-43 (5th Cir. 1973); United States v. Taylor, 437 F.2d 371, 375-76 (4th Cir. 1971); Harrison v. Settle, 151 F. Supp. 372, 375 (W.D. Mo. 1957); 
suggested: "It would be inhumane, and to a certain extent a denial of the right of trial upon the merits, to require one who has been disabled by the act of God from intelligently making his defense to plead or be tried for his life or liberty." ${ }^{67}$ It became black-letter law that the "trial and conviction of a person mentally and physically incapable of making a defense violates certain immutable principles of justice which inhere in the very idea of free government." ${ }^{68}$ First, an incompetent defendant might alone have exculpatory information that he is incapable of transmitting to counsel. ${ }^{69}$ Second, to try an incompetent defendant has been likened to permitting an adversary contest "in which the defendant, like a small boy being beaten by a bully, is unable to dodge or return the blows." ${ }^{, 70}$ Third, it has been suggested that the trial of an incompetent defendant transforms the adversary process from "a reasoned interaction between an individual and his community" into "an invective against an insensible object." 71 Fourth, "it seems essential to the philosophy of punishment that the defendant know why he is being punished, and such comprehension is to a great extent dependent upon involvement with the trial itself." 72 Actions against incompetent defendants were decried over three centuries ago by Lord Coke as "a miserable spectacle, both against law, and of extreme inhumanity and cruelty, and can be no example to others.",73

The rationale of the incompetency status is clear. It is fundamentally unfair to try a defendant who may not have - in the language of the U.S. Supreme Court, in Dusky v. United States - "sufficient present ability to consult with his lawyer with a reasonable degree of rational understanding [or] a rational as well as factual understanding of the proceedings against him."74

State v. Bowman, 681 A.2d 469, 470-71 (Me. 1996); RoESCH \& Golding, supra note 61, at 15-17; Winick \& DeMeo, supra note 61 , at 36 . It is clear that the court in Youtsey was referring to an incompetent, not an insane, defendant.

67. Jordan v. State, 135 S.W. 327, 328 (Tenn. 1911); see also Ausness, supra note 65, at 670 ("A seldom mentioned but powerful psychological reason for the requirement that the defendant be competent is that in order to satisfy the urge of the community to punish, the defendant must understand what he is being punished for.").

68. Sanders v. Allen, 100 F.2d 717, 720 (D.C. Cir. 1938) (citing Powell v. Alabama, 287 U.S. 45, 71 (1932))

69. See, e.g., United States v. Chisolm, 149 F. 284, 287 (S.D. Ala. 1906).

70. Ausness, supra note 65 , at 669. I acknowledge that much of this eighteenth-century language is hopelessly sanist and laden with stereotypes.

71. Note, Incompetency to Stand Trial, 81 HARV. L. REV. 454, 458 (1967).

72. $I d$. (footnote omitted).

73. 3 COKE, INSTITUTES 6 (1797). See generally Nobles v. Georgia, 168 U.S. 398 (1897).

74. Dusky v. United States, 362 U.S. 402, 402 (1960) (per curiam). Not all jurisdictions, of course, define fitness in the same way. In Australia, by way of example, unfitness is defined in the Crimes (Mental Impairment and Unfitness to Be Tried) Act 1997, in this manner:

When is a person unfit to stand trial?

(1) A person is unfit to stand trial for an offence if, because the person's mental processes are disordered or impaired, the person is or, at some time during the trial, will be-

(a) unable to understand the nature of the charge; or

(b) unable to enter a plea to the charge and to exercise the right to challenge jurors or the jury; or 
It also needs to be stressed that incompetency is a status, not a defense, and raising it is in no way a concession of factual guilt like invocation of the insanity defense. $^{75}$ The American Bar Association Standards for Criminal Justice underscore that the doctrine of incompetence to stand trial "has no bearing on guilt or innocence." 76 However, "[a]lthough there is nothing in the invocation of the incompetency status that at all concedes factual guilt ... it is assumed by all that the defendant did, in fact, commit the crime."77

Competency determinations are not easy ones to make. The Supreme Court acknowledged this in Drope v. Missouri:

[E]vidence of a defendant's irrational behavior, his demeanor at trial, and any prior medical opinion on competence to stand trial are all relevant in determining whether further inquiry is required, but... even one of these factors standing alone may, in some circumstances, be sufficient. There are, of course, no fixed or immutable signs which invariably indicate the need for further inquiry to determine fitness to proceed; the question is often a difficult one in which a wide range of manifestations and subtle nuances are implicated. ${ }^{78}$

But there is no question that the trial of a person who has been found to be incompetent violates every basic tenet of due process. ${ }^{79}$ Any reform that makes it more likely that there will be an increase in such trials must be rejected out of hand.

\footnotetext{
(c) unable to understand the nature of the trial (namely that it is an inquiry as to whether the person committed the offence); or

(d) unable to follow the course of the trial; or

(e) unable to understand the substantial effect of any evidence that may be given in support of the prosecution; or

(f) unable to give instructions to his or her legal practitioner.

(2) A person is not unfit to stand trial only because he or she is suffering from memory loss.
}

Crimes (Mental Impairment and Unfitness to Be Tried) Act 1997 (Vic) pt 2 (Austl.). Note that all subsections of this law are enumerated disjunctively, not conjunctively.

75. Criminal Justice Standards on Mental Health ch. 7, pt. IV (Am. Bar Ass'n 2015).

76. $I d$.

77. Perlin, Upside Down, supra note 20, at 246. It should be noted that in some other jurisdictions (e.g., Queensland, Australia), raising unfitness means that there is no examination of the alleged facts and that the defendant will automatically be detained or supervised as though she had committed the underlying crime. See, e.g., Mental Health Act 2000 (Qld) ch 7 pt 7 div 1 s 288(1) (Austl.). The Mental Health Court, to which criminal cases are transferred if mental health is an issue, may or must make a forensic order for the person's detention for involuntary treatment if the person:

(a) was of unsound mind when the alleged offence was committed; or

(b) is unfit for trial for the alleged offence and the unfitness for trial is of a permanent nature; or

(c) is unfit for trial for the alleged offence and the unfitness for trial is not of a permanent nature.

Id. (emphasis added). A forensic order is mandatory for those in category (c). Id. s 288(3).

78. Drope v. Missouri, 420 U.S. 162, 180 (1975).

79. See Dusky, 362 U.S. at 402. 
In this context, it is helpful to consider the Supreme Court's decision in Indiana v. Edwards. ${ }^{80}$ There, the Court grappled with the question of when a trial court could override a mentally-ill-but-competent-to-stand-trial criminal defendant's wishes to represent himself pro se. The Court held that the Constitution permits states to insist upon representation by counsel for those who are competent enough to stand trial but who still suffer from severe mental illness to the point that they are not competent to conduct trial proceedings by themselves. ${ }^{81}$ In coming to this conclusion, the Court carefully distinguished its earlier decision in Godinez $v$. $\operatorname{Moran}^{82}$ - which held that the standard for competency to stand trial, waive counsel, and plead guilty were identical-noting that Godinez did not deal with this specific question. ${ }^{83}$

In explaining the rationale of its decision, the Court employed concepts inherent to procedural justice: ${ }^{.4}$

Mental illness itself is not a unitary concept. It varies in degree. It can vary over time. It interferes with an individual's functioning at different times in different ways. The history of this case ... illustrates the complexity of the problem. In certain instances an individual may well be able to satisfy Dusky's mental competence standard, for he will be able to work with counsel at trial, yet at the same time he may be unable to carry out the basic tasks needed to present his own defense without the help of counsel. ${ }^{85}$

The Court here looked at dignitarian concerns, ${ }^{86}$ relying on McKaskle v. Wiggins ${ }^{87}$ for the proposition that "dignity and autonomy" of the individual "underlie [the] self-representation right." 88 The Court underscored that in the case of a defendant with an "uncertain mental state, the spectacle that could well result from his self-representation at trial is at least as likely to prove humiliating as ennobling." The Court found that proceedings must not only be fair; they must "appear fair to all who observe them." 90

80. 554 U.S. 164 (2008). On Supreme Court decision-making and dignitarian concepts in cases involving criminal punishments, see Jonathan Simon \& Stephen A. Rosenbaum, Dignifying Madness: Rethinking Commitment Law in an Age of Mass Incarceration, 70 U. MiAMI L. REv. 1, 29-32 (2015).

81. Edwards, 554 U.S. at 174.

82. 509 U.S. $389,402(1993)$.

83. Edwards, 554 U.S. at 173 .

84. See Michael L. Perlin, a Prescription for Dignity: Rethinking Criminal Justice and Mental Disabllity Law 83-88 (2013) [hereinafter Perlin, Prescription for Dignity].

85. Edwards, 554 U.S. at $175-76$.

86. See generally David C. Yamada, Dignity, "Rankism," and Hierarchy in the Workplace: Creating a "Dignitarian” Agenda for American Employment Law, 28 BERKELEY J. EMP. \& LAB. L. 305 (2007).

87. McKaskle v. Wiggins, 465 U.S. 168, 187-88 (1984) (finding appointment of standby counsel over self-represented defendant's objection is permissible).

88. Edwards, 554 U.S. at 176 (citing McKaskle, 465 U.S. at 176-77).

89. Id.

90. Id. at 177 (emphasis added) (quoting Wheat v. United States, 486 U.S. 153, $160(1988)$ ). Here, the Court quoted from an amicus brief reporting on a psychiatrist's reaction to observing a defendant - who, although 
This focus on dignity and the perception of justice, in addition to being the Court's "first implicit endorsement of important principles of therapeutic jurisprudence $^{91}$ in a criminal procedure context," 92 is central to this Article's thesis: how can our legal system allow a person who did not have the "sufficient present ability to consult with his lawyer with a reasonable degree of rational understanding [or] a rational as well as factual understanding of the proceedings against him" ${ }^{\text {"93 }}$ to go to trial?

\section{B. Insanity Defense}

I have been writing about the insanity defense for forty-five years, both in international $^{94}$ and domestic ${ }^{95}$ contexts. $^{96}$ I concede that U.S. insanity-defense jurisprudence is often incoherent, ${ }^{97}$ but this sad reality in no way minimizes, in my mind, the critical role it plays in any criminal-justice system that is fundamentally fair. As I will discuss below, discarding it would disregard millennia of experience and violate the most basic concepts of due process.

Few areas of our legal system have engendered as intense debate as the role of the insanity defense in the criminal-justice process. ${ }^{98}$ On the one hand, this "difficult subject" is seen as a reflection of "the fundamental moral principles of our criminal law." It rests on "assumptions that are older than the Republic" 100

satisfying the Dusky standard, was still mentally ill—attempt to conduct his own trial: "[H]ow in the world can our legal system allow an insane man to defend himself?" Id. (alteration in original).

91. See infra text accompanying notes $237-47$.

92. Perlin \& Cucolo, supra note $3, \S 13-2.4$. This endorsement can be juxtaposed with Justice Scalia's dissent, suggesting that the majority view is sanist (as the decision "permits [defendants with mental disabilities] to be deprived of a basic constitutional right-for their own good," Edwards, 554 U.S. at 189 (Scalia, J., dissenting), and thus opening up a question that has not been paid that much attention in the post-Godinez years: Is it more sanist to deprive persons with mental disabilities of a right that all other citizens have (i.e., that of self-representation) or to allow such persons to represent themselves in trials that may be nothing more than charades? See Michael L. Perlin, "Dignity Was the First to Leave": Godinez v. Moran, Colin Ferguson, and the Trial of Mentally Disabled Criminal Defendants, 14 BeHav. Sci. \& L. 61, $78-80$ (1996) [hereinafter Perlin, Dignity] (discussing the trial of Colin Ferguson).

93. Dusky v. United States, 362 U.S. 402, 402 (1960) (per curiam).

94. See Michael L. Perlin, The Insanity Defense in English-Speaking African Countries, 2 AFr. L. STUD. 73 (1969).

95. E.g., Michael L. Perlin, "The Borderline Which Separated You from Me": The Insanity Defense, the Authoritarian Spirit, the Fear of Faking, and the Culture of Punishment, 82 IowA L. REv. 1375, 1377-78 (1997) [hereinafter Perlin, Borderline]; Michael L. Perlin, Unpacking the Myths: The Symbolism Mythology of Insanity Defense Jurisprudence, 40 CASE W. REs. L. REv. 599 (1989) [hereinafter Perlin, Unpacking].

96. See generally PERLIN \& CuColo, supra note $3, \S 14-1.1$.

97. Perlin, Insanity Defense Jurisprudence, supra note 22, at 1.

98. See generally Perlin, Unpacking, supra note 95, at 601, 609-11; Perlin, Insanity Defense JurispruDENCE, supra note 22, at 3. See also Michael L. Perlin, "Where the Winds Hit Heavy on the Borderline": Mental Disability Law, Theory and Practice, "Us" and "Them," 31 LoY. L.A. L. REv. 775, 776-77 (1998) [hereinafter Perlin, Us and Them].

99. United States v. Lyons, 739 F.2d 994, 994 (5th Cir. 1984) (Rubin, J., dissenting). The majority opinion in Lyons is found at 731 F.2d 243 (5th Cir. 1984).

100. See Lyons, 739 F.2d at 995 (Rubin, J., dissenting) (citing HaLE eT AL., supra note 62). 
and on "beliefs about human rationality, deterrability, and free will"; ${ }^{101}$ and it serves as a bulwark of the law's "moorings of condemnation for moral failure." 102

As stated by an Ohio court, "the insanity defense goes to the very root of our criminal justice system." ${ }^{103}$ On the other hand, the insanity defense is attacked on the basis of a series of myths that have been firmly and conclusively disproved by all the valid and reliable statistical and empirical evidence. ${ }^{104}$

Notwithstanding the insanity defense's relative numerical insignificance, ${ }^{105}$ it is rooted in moral principles of excuse that are accepted "in both ordinary human interaction and criminal law,"106 and it continues to serve as a "surrogate for resolution of the most profound issues in criminal justice." ${ }^{107}$ As Professor Susan Bandes has suggested, "[t]he evolution of the insanity defense represents a continuing struggle to incorporate expanding medical knowledge into our system of laws." 108

Historically, the defense has been "a major component of the Anglo-American common law for over 700 years." "109 Rooted in Talmudic, Greek, and Roman history, its forerunners can actually be traced back over 3000 years. ${ }^{10}$ The sixth-century Code of Justinian explicitly recognized that the "insane" were not responsible for their acts. ${ }^{111}$ By the ninth century, the "Dooms of Alfred"112 acknowledged that an impaired individual who could not "acknowledge or confess his offences" was absolved from personally making restitution. ${ }^{113}$ The defense's

101. Richard J. Bonnie \& Christopher Slobogin, The Role of Mental Health Professionals in the Criminal Process: The Case for Informed Speculation, 66 VA. L. REv. 427, 448 (1980).

102. John Monahan, Abolish the Insanity Defense? - Not Yet, 26 Rutgers L. Rev. 719, 731 (1973) (quoting Joseph M. Livermore \& Paul E. Meehl, The Virtues of M'Naghten, 51 Minn. L. REv. 789, 797 (1967)).

103. State v. Curry, 543 N.E.2d 1228, 1230 (Ohio 1989).

104. See generally Perlin, Nine Myths, supra note 25. See also infra text accompanying note 152 .

105. See Perlin, Nine Myths, supra note 25, at 8-10. By way of example, in New Jersey, the NGRI plea was successful in $0.05 \%$ of all cases handled by the state public defender's office in one year. See Joseph H. Rodriguez, Laura M. LeWinn \& Michael L. Perlin, The Insanity Defense Under Siege: Legislative Assaults and Legal Rejoinders, 14 RuTGERS L.J. 397, 401-02 (1983). There were 141 successful insanity defenses over an eight-year period. $I d$.

106. Stephen J. Morse, Excusing the Crazy: The Insanity Defense Reconsidered, 58 S. CAL. L. REv. 777, 782 (1985).

107. Lincoln Caplan, The Insanity Defense and the Trlal of John W. Hinckley, Jr. 127 (1984).

108. Susan Bandes, Developments in the Insanity Defense, 10 BARRISTER 41, 45 (1983).

109. See Robert L. Sadoff \& Frank M. Dattilio, Criminal Responsibility, in HandBook of Forensic Assessment: Psychological and Psychiatric Perspectives 121 (Eric Y. Drogin et al. eds., 2011 ); 2 H. Bracton, De Legibus et Consuetudinibus Angliae 424 (Longman \& Thorne trans., 1968). Professor Jonas Robitscher and a colleague date the "firm[] entrench[ment]" of the insanity defense to the ninth century. Jonas Robitscher \& Andrew Ky Haynes, In Defense of the Insanity Defense, 31 Emory L.J. 9, 10 (1982).

110. For an overview dating to the Code of Hammurabi, from a clinician's perspective, see Daniel $P$. Greenfield, Criminal Responsibility from a Clinical Perspective, 37 J. PSYCHIATRY \& L. 7 (2009).

111. 2 S.P. SCOtT, The Civil Law 259 (1973).

112. Dooms were laws promulgated by Anglo-Saxon and Danish kings; among the most famous and best preserved are those issued by King Alfred, between 890 and 900 A.D. See Daniel R. Coquillette, The Lessons of Anglo-Saxon "Justice," 2 GREEN BAG 251, 253 (1999).

113. 2 Nigel WaLker, Crime and InSanity in England 219 (1968). 
modern roots can be traced at least as far back as a 1505 case-the first recorded jury verdict of insanity ${ }^{114}$-but it is clear that even prior to that case, juries considered "acquittal to be the appropriate result" in certain insanity-defense cases. ${ }^{115}$ Further, William Lambard's late-sixteenth-century text on criminal responsibility ${ }^{116}$ suggested that the insanity defense was already "well settled" in England, ${ }^{117}$ and Sir Coke's 1817 treatise "gave the law the familiar maxim that "a madman is only punished by his madness." 118 In short, the defense has been a part of the fabric of the law since "time immemorial."

\section{The Indispensability of the Incompetency Status and Insanity Defense}

As this brief historical overview should make clear, both the incompetency status and the insanity defense are indispensable segments of a mature and coherent legal system. It is true that a handful of U.S. states have abolished the insanity defense, ${ }^{119}$ but clearly there must be at least a mens rea exception. ${ }^{120}$

Importantly, commentators have been uniformly critical of the abolitionist states. One critic of Kansas's law said:

Kansas's mens rea approach is not a satisfactory alternative to the former insanity defense. Even though the approach is relatively simple and straightforward when compared to M'Naghten, it is too narrow in its application. It unfairly punishes people who are completely unable to understand the nature

114. See id. at $25-26$.

115. See Sadoff \& Dattilio, supra note 109 , at 121.

116. William Lambarde was a sixteenth-century scholar whose definition of insanity was quoted by the Third Circuit in 1961:

If a mad man or a naturall foole, or a lunatike in the time of his lunacie, or a childe y apparently hath no knowledge of good nor euil do kill a ma, this is no felonious acte, nor any thing forfeited by it ... for they cannot be said to have any understanding wil. But if upo examinatio it fal out, $y$ they knew what they did, \& y it was ill, the seemth it to be otherwise.

United States v. Currens, 290 F.2d 751, 764 (3d Cir. 1961). The quoted volume was apparently written as a handbook for justices of the peace. See Robitscher \& Haynes, supra note 109, at 12.

117. William Lambarde, Eirenarcha, or of the Office of the Justices of the Peace (1581), reprinted in JOHN Biggs, JR., The Guilty Mind: Psychiatry and the Law of Homicide 47-56, 81-88 (1955).

118. Robitscher \& Haynes, supra note 109, at 12 n.10 (quoting COKE, supra note 73 , at $247 \mathrm{a}-\mathrm{b}$ ("furiosus solo furore punitur")).

119. See Perlin \& Cucolo, supra note $3, \S 14-1.5$.

120. See Clark v. Arizona, 548 U.S. 735 (2006) (finding Arizona's use of insanity test stated solely in terms of capacity to tell whether act charged as crime was right or wrong did not violate U.S. Constitution). Clark has "spawned some of the most caustic commentary in decades responding to a Court decision in this area of law and policy." Perlin \& CuColo, supra note $3, \S 14-1.2 .8$. Consider the titles of some of the articles flaying the Clark Court for the narrowness of its decision. See, e.g., Henry F. Fradella, How Clark v. Arizona Imprisoned Another Schizophrenic While Signaling the Demise of Clinical Forensic Psychology in Criminal Courts, 10 N.Y.C. L. REV. 127 (2006); Elizabeth Aileen Smith, Did They Forget to Zero the Scales?: To Ease Jury Deliberations, the Supreme Court Cuts Protection for the Mentally Ill in Clark v. Arizona, 26 L. \& INEQ. 203 (2008); Susan D. Rozelle, Fear and Loathing in Insanity Law: Explaining the Otherwise Inexplicable Clark v. Arizona, 58 CASE W. Res. L. Rev. 19 (2007). 
and consequences of their actions. Our criminal justice system has been premised on the belief that only people who are responsible for their actions should be punished. ${ }^{121}$

The General Comment rejects this bedrock premise of the criminal justice, allegedly in support of universal capacity. Nothing could be more misguided.

\section{The General Comment}

Nearly two decades ago, I wrote this in an article about the "borderlines" around the insanity defense that needed to be considered:

I believe that the insanity defense has always been a symbol and a screen. ${ }^{122}$ It has always served as a litmus test for how we feel about a host of social, political, cultural and behavioral issues that far transcend the narrow questions of whether a specific defendant should be held responsible for what - on its surface-is a criminal act, or how responsibility should be legally calibrated, or of the sort of institution in which a successful insanity acquittee should be housed.

At its base, how we feel about the insanity defense illuminates how we feel about the relationships between mental health and the law, between mental health professionals and judges, between criminals and victims, between the media and the trial process, between the law-abiding and the law-flaunting. In short, our feelings about the insanity defense reflect our feelings about borderlines.... ${ }^{123}$

Let us start with the question of incompetency. The Comment on Article 14 begins: "Liberty and security of the person is one of the most precious rights to which everyone is entitled. In particular, all persons with disabilities, and especially persons with mental disabilities or psychosocial disabilities are entitled to liberty pursuant to article 14 of the Convention." 124 This is certainly one of the foundational CRPD rights. But the Comment moves from there to the call to abolish the incompetency status. In a section headed "Detention of persons unfit to plead in criminal justice systems," the Comment states: "The committee has established that declarations of unfitness to stand trial and the detention of persons based on that declaration is contrary to article 14 of the convention since it deprives the

121. Marc Rosen, Insanity Denied: Abolition of the Insanity Defense in Kansas, 8 KAN. J.L. \& PUB. POL'Y 253, 262 (1999). See generally R. Michael Shoptaw, M'Naghten Is a Fundamental Right: Why Abolishing the Traditional Insanity Defense Violates Due Process, 84 Miss. L.J. 1101 (2015).

122. I use the word "screen" self-consciously, drawing on Judge Adams's dissent in Virgin Islands v. Fredericks, 578 F.2d 927, 937 (3d Cir. 1978) (finding that criminal law operates "as a screen upon which the community ... project[s] its visions of criminal justice"). I do not believe that the community's vision of criminal justice is one that consigns persons with serious mental illness to prisons in which they are the most likely to be tortured and brutalized. See infra text accompanying notes 205-08.

123. Perlin, Borderline, supra note 95 , at $1377-78$.

124. CRPD, Statement on Article 14, supra note 13. Of course, I have no quarrel whatsoever with this statement. 
person of his or her right to due process and safeguards that are applicable to every defendant."125

This astonishing leap makes no sense whatsoever. Consider what Article 14 actually says:

1. States Parties shall ensure that persons with disabilities, on an equal basis with others:

(a) Enjoy the right to liberty and security of person;

(b) Are not deprived of their liberty unlawfully or arbitrarily, and that any deprivation of liberty is in conformity with the law, and that the existence of a disability shall in no case justify a deprivation of liberty.

2. States Parties shall ensure that if persons with disabilities are deprived of their liberty through any process, they are, on an equal basis with others, entitled to guarantees in accordance with international human rights law and shall be treated in compliance with the objectives and principles of the present Convention, including by provision of reasonable accommodation. ${ }^{126}$

Nothing in this article offers the slightest shred of support to the abolition of the incompetency status. First, as indicated earlier, international human rights have, for decades, included the right to a fair trial. ${ }^{127}$ The trial of a person who cannot comprehend what is going on or who cannot cooperate with her counsel cannot be a fair trial. ${ }^{128}$ Articulation of the incompetency status in no way indicates factual guilt. ${ }^{129}$ But if a defendant cannot articulate to her lawyer what her defense is, what other witnesses might be able to shed light on the underlying facts, or what her relationship with the alleged victim was, then it is incomprehensible to think that, in all but the rarest cases, such a trial will lead to an acquittal. ${ }^{130}$

Second, the Comment does not address the critical question of what happens if such a person chooses to waive counsel and represent herself. This is an issue that the Supreme Court has grappled with twice in recent years. ${ }^{131}$ Its more recent decision, in Indiana v. Edwards, held that states could insist upon the representation by counsel for those who are competent enough to stand trial but who still

125. Id.

126. CRPD, supra note 1 , art. 14.

127. See ICCPR, supra note 54, art. 14; see also, e.g., Charles Chernor Jalloh, Does Living by the Sword Mean Dying by the Sword?, 117 PENN ST. L. REv. 707, 740 (2013).

128. See Dusky v. United States, 362 U.S. 402, 402 (1960) (per curiam).

129. See Criminal Justice Standards on Mental Health, supra note 75.

130. As noted, supra text accompanying note 70 , over 200 years ago, a court noted that to allow an incompetent defendant to be tried is like permitting an adversary contest "in which the defendant, like a small boy being beaten by a bully, is unable to dodge or return the blows." Ausness, supra note 65, at 669 .

131. See Godinez v. Moran, 509 U.S. 389 (1993) (establishing unitary test for competency to stand trial, plead guilty, and waive counsel), modified in Indiana v. Edwards, 554 U.S. 164 (2008) (holding right to selfrepresentation not absolute, and State could insist attorney be appointed to represent mentally ill defendant though defendant found competent to stand trial). I discuss both cases in this context in Michael L. Perlin \& Alison J. Lynch, "All His Sexless Patients": Persons with Mental Disabilities and the Competence to Have Sex, 89 WASH. L. Rev. 257, 263 n.21 (2014) [hereinafter Perlin \& Lynch, Sexless Patients]. 
suffer from severe mental illness to the point that they are not competent to conduct trial proceedings by themselves. ${ }^{132}$ Such self-representation at trial will not "affirm the dignity" of a defendant who lacks the mental capacity to conduct his defense without the assistance of counsel. ${ }^{133}$ The trial of an incompetent defendant mocks any definition of dignity, ${ }^{134}$ one of the basic tenets of the CRPD. ${ }^{135}$

Third, even assuming there is any textual support within Article 14 for this tortured reading, it is black-letter law that any piece of legislation must be read in pari materia. ${ }^{136}$ It is axiomatic that a statute "must, to the extent possible, ensure that the statutory scheme is coherent and consistent." 137 Consider again other articles of the CRPD: mandating "[r]espect for inherent dignity"; 138 "[f]reedom from torture or cruel, inhuman or degrading treatment or punishment"; 139 "[f]reedom from exploitation, violence and abuse"; ${ }^{140}$ a right to protection of the "integrity of the person"; ${ }^{41}$ and the retention of any provisions "more conducive to the ... rights of persons with disabilities." ${ }^{142}$ Any interpretation of Article 14 that makes it more likely that factually innocent individuals will be convicted and incarcerated and that makes it less likely that the individual's trial will be "fair" must be rejected.

Turn now to the insanity defense. On the one hand, some states have abolished the defense, ${ }^{143}$ and the defense is not available in some other nations. ${ }^{144}$ On the other hand, it should be noted that the defense is available in the International

132. Edwards, 554 U.S. at 178.

133. Id. at 176 (citing McKaskle v. Wiggins, 465 U.S. 168, 176-77 (1984)).

134. See generally Perlin, Dignity, supra note 92.

135. CRPD, supra note 1, art. 3(a).

136. Statutes must be "taken, read, and construed together, each enactment in reference to the other, as though they were parts of one and the same law." See Peraza v. State, 467 S.W.3d 508, 520 n.29 (Tex. Crim. App. 2015) (quoting Jones v. State, 396 S.W.3d 558, 561-62 (Tex. Crim. App. 2013)).

137. Ali v. Fed. Bureau of Prisons, 552 U.S. 214, 222 (2008); see also Kevin Hembree, Note, Of Two Minds About Plain Meaning: The Supreme Court's Interpretation of the Word "Any" in 28 U.S.C. $\$ 2680($ c), 60 MERCER L. REv. 1487, 1499 n.121 (2008) ("[A] statute should be both internally consistent and consistent with other similar statutes." (citing Linda D. Jellum \& David Hricik, Modern Statutory interpretation: Problems, THeORIES, AND LAWYering STRATEGIES 172-73 (2006))).

138. CRPD, supra note 1 , art. 3(a).

139. Id. art. 15 .

140. Id. art. 16 .

141. Id. art. 17.

142. Id. art. $4(4)$.

143. See supra notes $97-99$ and accompanying text.

144. See John Q. La Fond, Observations on the Insanity Defense and Involuntary Civil Commitment in Europe, 7 U. Puget Sound L. Rev. 527 (1984) (defense abolished in Sweden). Though, internationally, insanity is generally "widely recognized" as a defense to crime. See William A. Schabas, International Norms on Execution of the Insane and the Mentally Retarded, 4 CRIM. L.F. 95, 95 (1993). On the infrequency of its use in Norway, see Colin Jacobsen \& Daniel Maier-Katkin, Breivik's Sanity: Terrorism, Mass Murder, and the Insanity Defense, 37 Hum. RTs. Q. 137 (2015); Michael S. Moore, The Quest for a Responsible Responsibility Test: Norwegian Insanity Law after Breivik, 9 Crim. L. \& PHIL. 645 (2015). 
Criminal Court. ${ }^{145}$ As I have often noted in other contexts, I believe that abolition is wrongheaded, counterproductive, and likely a violation of due process. ${ }^{146}$ Twenty years ago, I charged that "[t]he intellectual vacuity among politicallymotivated abolitionists is illuminated by the striking lack of interest that has been shown in the empirical data in those jurisdictions where abolition has been attempted." ${ }^{147}$ I have also argued that the abolition movement has been fueled by the "common wisdom"148 that the insanity defense is an abused, over-pleaded, and over-accepted loophole used as a last-gasp plea solely in grisly murder cases to thwart the death penalty; that most successful pleaders are not truly mentally ill; that most acquittals follow sharply contested "battles of the experts"; and that most successful pleaders are sent for short stays to civil hospitals. ${ }^{149}$ Although each of these myths has been clearly, definitively, and empirically disproved, ${ }^{150}$ all of them remain powerful and show no sign of abating. ${ }^{151}$ The abolitionist movement has been fueled by politicians who focus on abolition as a panacea for urban crime problems, ${ }^{152}$ and legislative candidates point to insanity-defense support as indicia of an opponent's being soft on crime. ${ }^{153}$ Professor Stephen Morse has concluded that "[w]e should not abolish the insanity defense unless we truly believe that every perpetrator of a criminal act deserves to be punished, no matter how crazy." 154

But these abolitionist arguments pale in comparison with the Comment on Article 12 that reads the CRPD to purportedly demand the abolition of the defense in all signatory nations. ${ }^{155}$ According to that Comment:

In the area of criminal law, recognition of the legal capacity of persons with disabilities requires abolishing a defence based on the negation of criminal responsibility because of the existence of a mental or intellectual disability.

145. See Rome Statute of the International Criminal Court, art. 31(1)(a), Jul. 17, 1998, 2187 U.N.T.S. 3.

146. See Perlin, Insanity Defense Jurisprudence, supra note 22, at 133-39.

147. Id at 140. Empirically, and ironically, given the Comment to Article 14, in those jurisdictions in which the insanity defense is abolished, there is often a statistically significant increase in the number of defendants found permanently incompetent to stand trial. See Henry J. Steadman et al., Maintenance of an Insanity Defense Under Montana's "Abolition" of the Insanity Defense, 146 AM. J. PSychlatRy 357, 359-60 (1989).

148. This "common wisdom" is an exemplar of what I refer to as false "ordinary common sense" ("OCS"), which has contaminated insanity-defense jurisprudence. See Perlin, Insanity Defense Jurisprudence, supra note 22 , at $305-10$.

149. Perlin, Unpacking, supra note 95, at 707-08.

150. See Perlin, Nine Myths, supra note 25.

151. Perlin, Unpacking, supra note 95, at 707. See generally United States v. Lyons, 739 F.2d 994, $995-99$ (5th Cir. 1984) (Rubin, J., dissenting) (discussing the myths surrounding the insanity defense).

152. Such arguments were raised by certain members of Congress during the debate on the Insanity Defense Reform Act that "parrot[ed] medieval views of the mentally disabled criminal defendant." PerLin, InSANiTY DEFENSE JURISPRUDENCE, supra note 22, at 18. These pro-abolition statements by politicians were based on empirical and behavioral myths. See id. at 18-24.

153. Perlin, Borderline, supra note 95 , at $1406-07$.

154. Morse, supra note 106 , at 836.

155. U.N. Human Rights Council, supra note 14, II 47. 
Instead disability-neutral doctrines on the subjective element of the crime should be applied, which take into consideration the situation of the individual defendant. $^{156}$

I do not believe that these comments were drafted maliciously or with the intent to harm persons with disabilities. But I believe this will be their effect, if implemented. $^{157}$

This has been the topic of stunningly little commentary in legal literature to this point. Professor Christopher Slobogin has written carefully about this Comment. He has concluded that it fits within the model of what he calls the "integrationist" approach to criminal law - providing persons with mental disabilities with "all of the defenses that are available to criminal defendants without mental disabilities." ${ }^{158}$ With this in mind, he recasts the insanity defense in this way:

A person shall be excused for an offense if, at the time of the offense, he or she (a) lacked the subjective mental state for the conduct, circumstance, or result element of the crime; (b) believed circumstances existed that, if true, would have justified the offense; (c) believed circumstances existed that, if true, would have amounted to duress; provided that he or she did not cause any of these mental states [by, inter alia, purposely avoiding treatment, aware that such states would occur without such treatment]. ${ }^{159}$

156. Id.

157. Although one should always be wary of "slippery slope" arguments, it does not appear to be a stretch to suggest that the abolition of the incompetency status and the insanity defense would also call into question the continued viability of U.S. Supreme Court decisions such as Ford v. Wainwright, 477 U.S. 399 (1986); Atkins v. Virginia, 536 U.S. 304 (2002); and Hall v. Florida, 134 S. Ct. 1986 (2014), all proscribing the execution of the "presently insane" and persons with intellectual disabilities. See generally PERLIN \& CuCOLO, supra note 3, § 17-4 (extensively discussing this line of cases); Michael L. Perlin, Mental Disability and the Death Penalty: The Shame of the States, 45-84 (2013) [hereinafter Perlin, Shame] (same).

158. Slobogin, Eliminating Mental Disability, supra note 25, at 304; see also Christopher Slobogin, An End to Insanity: Recasting the Role of Mental Disability in Criminal Cases, 86 VA. L. REv. 1199 (2000) [hereinafter Slobogin, End to Insanity]. For a full explication of this theory, see Christopher Slobogin, A Defense of the Integrationist Test as a Replacement for the Special Defense of Insanity, 42 TEX. TECH L. REV. 523 (2009) [hereinafter Slobogin, Integrationist Test]. Slobogin premises his argument, in large part, on the argument that "the subjectification of traditional criminal defenses is normatively required." Slobogin, Eliminating Mental Disability, supra note 25, at 305.

159. Slobogin, Eliminating Mental Disability, supra note 25, at 306 (alteration in original) (quoting Christopher Slobogin, Minding Justice: Laws that Deprive People with Disability of Life and Liberty 56 (2006) [hereinafter Slobogin, Minding Justice]). Slobogin's test has been endorsed in, for example, Arnold H. Loewy, The Two Faces of Insanity, 42 Tex. Tech L. REv. 513 (2009) (arguing for a similar approach), though other scholars have called it "arbitrary," Richard J. Bonnie, Why "Appreciation of Wrongfulness" Is a Morally Preferable Standard for the Insanity Defense, Presentation at the Conference on the Affirmative Defense of Insanity in Texas 59 (Feb. 7, 2003) (transcript available at http://www.txpsych.org/wp-content/uploads/2016/02/ insanitytranscript.pdf), and have criticized it for failing to exculpate all who should be exculpated by an insanity defense, see, e.g., Susan D. Rozelle, Pure Insanity, 42 Tex. Tech L. Rev. 543 (2009). The support for and criticisms of this test are discussed in Slobogin, Integrationist Test, supra note 158, at 523-24, 523 n.5, 524 nn. $6-8$. 
In short, Slobogin—although recommending the elimination of the insanity defense per se-endorses a finding of non-culpability in certain cases. He would thus find a defendant not to be culpable if the defendant claimed, for example, "I shot him because it was necessary to save the world from destruction by the Klingon empire" (duress and mistake of fact), or, "I shot him because God [or the devil] ${ }^{160}$ told me to" (mistake of fact and, of course, a parallel to the biblical story of Abraham and his son, as dramatized in the Bob Dylan song that gave this Article its title). This is an insanity defense but is merely not characterized by Slobogin as such. It must also be noted that in some jurisdictions, duress is not allowed as a defense to homicide; ${ }^{161}$ in those jurisdictions, presumably, Slobogin's formulation would not be allowed.

Slobogin has relied, in part, on my many discussions of sanism and how it poisons all jurisprudence, in support of his position that the insanity defense must be recast, noting that "[o]ne particularly insidious sanist notion, clearly belied by the data, is that those with mental illness are abnormally dangerous."162 I agree certainly, but I do not see this observation as requiring abolition of the insanity defense. First, there is no causal correlation between the use of the insanity defense and an underlying dangerous crime. ${ }^{163}$ My research indicates that a victim died in only a minority of cases in which the insanity defense was pleaded. ${ }^{164}$ Second, the assertion of an insanity defense need not necessarily lead to subsequent long-term institutionalization. ${ }^{165}$ Also, if the evidence that is developed shows that a

160. See generally Grant H. Morris \& Ansar Haroun, "God Told Me To Kill": Religion or Delusion?, 38 SAN Diego L. Rev. 973 (2001). The "Klingon Empire" hypothetical is one that I often use in teaching this topic.

161. E.g., Commonwealth v. Vasquez, 971 N.E.2d 783, 792 (Mass. 2012); Joshua Dressler, Reflections on Dudley and Stephens and Killing the Innocent: Taking a Wrong Conceptual Path, in THE SANCTITY OF LIFE AND the Criminal Law: The Legacy of Glanvllle W llliams 126, 128-29 (Dennis J. Baker \& Jeremy Horder eds., 2013) (discussing UK law). See generally Steven J. Mulroy, The Duress Defense's Uncharted Terrain: Applying It to Murder, Felony Murder, and the Mentally Retarded Defendant, 43 SAN DIEGo L. REv. 159, 172-73 (2006) (noting that most states, the federal courts, the U.S. military justice system, and virtually all international common-law jurisdictions follow the common-law rule that duress cannot be a defense to murder).

Further, there are jurisdictions that reject a subjective self-defense standard, and no jurisdiction allows a fully subjective self-defense standard. See, e.g., V.F. Nourse, Self-Defense and Subjectivity, 68 U. CHI. L. REv. 1235, 1291 (2001); see also Alafair S. Burke, Rational Actors, Self-Defense, and Duress: Making Sense, Not Syndromes, out of the Battered Woman, 81 N.C. L. REv. 211, 287 n.308 (2002) (noting that under the Model Penal Code, when a defendant's belief is not objectively reasonable, self-defense operates only to reduce a crime requiring purpose or knowledge to a lesser offense requiring only recklessness or negligence).

162. Slobogin, End to Insanity, supra note 158, at 1244 (footnote omitted).

163. See Perlin, Insantty Defense Jurisprudence, supra note 22, at 109 (citing Rodriguez, LeWinn \& Perlin, supra note 105, at 402). Subsequent multistate studies revealed that less than one-sixth of all insanity pleaders were charged with murder. See Lisa A. Callahan et al., The Volume and Characteristics of Insanity Defense Pleas: An Eight-State Study, 19 Bull. Am. ACAd. Psychiatry \& L. 331, 336 (1991).

164. In one jurisdiction where this issue was carefully studied, less than one-third of successful insanity pleas involved cases in which a victim died (a category far broader than simply "murder"). See PerLin, InSANITY DEFENSE JURISPRUDENCE, supra note 22, at 109; Callahan et al., supra note 163, at 336; see also supra text accompanying note 163 .

165. Insanity acquittals do lead to such long-term, post-acquittal commitments in many U.S. jurisdictions, following the Supreme Court's utterly wrongheaded decision in Jones v. United States, 463 U.S. 354 (1983) 
defendant committed a certain act to save us from the Klingon empire or because God (or the devil) ordained it, the jurors should logically conclude that the defendant has a profound mental illness. I cannot believe that saying this mental illness is part of a mistake-of-fact or duress defense will somehow diminish juror sanism.

Beyond semantics, I disagree with Slobogin on two points. First, he discusses the famous case of John Hinckley, the man who shot President Ronald Reagan and was subsequently found not guilty by reason of insanity. ${ }^{166}$ At the time that Hinckley was tried, the federal court in the District of Columbia employed the American Law Institute-Model Penal Code ("ALI-MPC") insanity-defense standard, under the then-prevailing case, United States v. Brawner. ${ }^{167}$ Slobogin points

(rejecting arguments that it was unconstitutional to retain insanity acquittees for longer periods of time than the maximum sentence for the underlying crime). But there are other jurisdictions, see, e.g., State v. Krol, 344 A.2d 289, 297 (N.J. 1975) (providing expanded procedural-due-process rights for insanity acquittees), that reject this and take the position that "[t]he labels 'criminal commitment' and 'civil commitment' are of no constitutional significance," id. I have noted that there is "great irony in the fact that the most expansive due process decision in this area-Krol-involves a defendant charged with murder, while the most restrictive decision-Jonesinvolves a defendant charged with shoplifting." Perlin, Misdemeanor Outlaw, supra note 10, at 213 n.133. Notwithstanding the $\mathrm{Krol}$ decision, insanity acquittees are often — because of sanist and political fears-retained in maximum-security institutions for far longer than is clinically required. See, e.g., Grant T. Harris, Marnie E. Rice \& Catherine A. Cormier, Length of Detention in Matched Groups of Insanity Acquittees and Convicted Offenders, 14 InT'L J.L. \& PSychiatry 223 (1991); Eric Silver, Punishment or Treatment?: Comparing the Lengths of Confinement of Successful and Unsuccessful Insanity Defendants, 19 LAW \& Hum. BeHAV. 375 (1995). On how, in this context, persons with serious mental illness must be "rescue[d] ... from 'the vicissitudes of political controversy," "and the judicial branch must "establish basic tenets of decency 'as legal principles to be applied by the courts,"' see Ellen Byers, Mentally Ill Criminal Offenders and the Strict Liability Effect: Is There Hope for a Just Jurisprudence in an Era of Responsibility/Consequences Talk?, 57 ARK. L. REv. 447, 537 (2004) (quoting W. Va. State Bd. of Educ. v. Barnette, 319 U.S. 624, 638 (1943)).

Consider here the most famous U.S. insanity case of the twentieth century, that of John W. Hinckley. The final report of the National Institute of Mental Health's Ad Hoc Forensic Advisory Panel, which was specifically selected to review the policies and procedures of the St. Elizabeth's Hospital Forensic Division, where Hinckley was housed, underscores the pragmatic issues afoot in such a case. The report notes that "[f]rom the perspective of the Hospital, in controversial cases such as Hinckley, the U.S. Attorney's office can be counted upon to oppose any conditional release recommendation." Final Report of the National Institute of Mental Health (NIMH) Ad Hoc Forensic Advisory Panel, 12 Mental \& Physical Disability L. Rep. 77, 96 (1988). The bureaucratic issue is not one of moral philosophy, of treatment philosophy, or of clinical conditions; it is the political reality that the government will be sure to oppose the release of a "controversial" patient. See id.

166. For subsequent post-acquittal developments in Hinckley's case, see United States v. Hinckley, 462 F. Supp. 2d 42 (D.D.C. 2006) (stating mother was capable of continuing to serve as responsible party of patient's conditional release visits to her home); United States v. Hinckley, 292 F. Supp. 2d 125, 147-48 (D.D.C. 2003) (denying unsupervised conditional release to custody of parents for thirty-six hours, but granting "highly structured, limited conditional release" from hospital under supervision of parents). Most recently, Hinckley was allowed conditional release of seventeen days each month to his mother's home, with certain conditions. See $35 \mathrm{~F}$. Supp. 3d 4 (D.D.C. 2014). Since then, he has been ordered released from St. Elizabeth's, after thirty-five years. See Zoe Tillman, President Reagan Shooter John Hinckley Jr. Granted Release, http:/www.law.com/sites/almstaff/ 2016/07/27/president-reagan-shooter-john-hinkley-jr-granted-release/?slreturn $=20160629095406$.

167. 471 F.2d 969, 973 (D.C. Cir. 1972) ("A person is not responsible for criminal conduct if at the time of such conduct as a result of mental disease or defect he lacks substantial capacity either to appreciate the criminality [wrongfulness] of his conduct or to conform his conduct to the requirements of the law." (alteration in original) (quoting Model Penal Code § 4.01(1) (Proposed Official Draft 1962))). 
out that Hinckley would not have had a defense under his scheme, concluding that the lack-of-appreciation and inability-to-conform prongs ${ }^{168}$ of the insanitydefense test under which Hinckley was tried were "overbroad." ${ }^{169}$ I disagree, as I believe that the ALI-MPC test-employed at that time in the federal district of the District of Columbia, where Hinckley was tried-was the appropriate test and was, if anything, too narrow. ${ }^{170}$

But, more importantly, I believe that Hinckley's acquittal flowed not from the wording of the test but rather from two other sources: (1) how the jurors perceived the expert witnesses in Hinckley's case (finding the defendant's witnesses more trustworthy and believable); ${ }^{171}$ and, more importantly, (2) under federal law at the time Hinckley was tried, once insanity was raised, the burden of proof shifted to the government to disprove insanity beyond a reasonable doubt. ${ }^{172}$ This burden was changed by the Insanity Defense Reform Act ("IDRA") in 1984, ${ }^{173}$ and I have serious doubts as to whether Hinckley would have any chance of being acquitted had the burden of proof required by the IDRA been in place. ${ }^{174}$ In short, it was not the use of the "expansive" substantive so-called "Brawner test" 175 that led to the not-guilty-by-reason-of-insanity ("NGRI") verdict in Hinckley's case, but rather the more generous burden of proof. ${ }^{176}$ The other point to make here is that the

168. See supra note 167 and accompanying text.

169. Slobogin, Eliminating Mental Disability, supra note 25, at 307.

170. See generally Perlin, INSANity DefenSe JuRISPRUdENCE, supra note 22, at 89-91.

171. See CAPLAN, supra note 107 , at 127.

172. See, e.g., Cynthia G. Hawkins-León, "Literature as Law": The History of the Insanity Plea and a Fictional Application Within the Law \& Literature Canon, 72 TeMP. L. REv. 381, 400-01 (1999).

173. Perlin, InSanity Defense Jurisprudence, supra note 22, at 96-100.

174. Per the prevailing law in the District of Columbia at the time of the Hinckley trial, once the defendant raised insanity, the Government had to disprove it beyond a reasonable doubt. See Trial Tr. vol. 83, United States v. Hinckley, Crim. No. 81-306 (D.D.C. June 18, 1982), reprinted in The Insanity Defense: Hearings Before the Committee on the Judiclary of the United States Senate, 97th Cong., 2d Sess. 183, 191-92 (1982). The following instruction was given to the Hinckley jury:

The burden is on the Government to prove beyond a reasonable doubt either that the defendant was not suffering from a mental disease or defect on March 30, 1981, or else that he nevertheless had substantial capacity on that date both to conform his conduct to the requirements of the law and to appreciate the wrongfulness of his conduct.

Id. Under the Insanity Defense Reform Act, this burden shifted to the defendant to prove by clear and convincing evidence. See 18 U.S.C. $\$ 17$ (b).

175. See supra note 168 and accompanying text. On the differences between the Brawner test and the M'Naghten test, see PerLin, InSANITy DeFEnSE JuRISPRUdence, supra note 22, at 89-91.

176. But see Gary B. Melton et al., Psychological Evaluations for the Courts: A Handbook for Mental Health Professionals and Lawyers 218 (1987) (questioning the significance of the burden of proof). It is impossible, of course, to pinpoint exactly why a jury chose to decide a case as it did, and there were other potential confounders here as well (e.g., the defense's use of then-nascent neuroscientific evidence; and the racial composition of the jury, see generally CAPLAN, supra note 107, at 127), but, certainly, the verdict in the Hinckley case was a major motivating force to include the change in burden in the Insanity Defense Reform Act of 1984. See 18 U.S.C. \& 17(b); U.S. Code Cong. \& ADmin. News, 98th Cong., 2d Sess. 3182, 3412 (1984) ("The Committee is of the view that a more rigorous requirement than proof by a preponderance of the evidence is necessary to assure that only those defendants who plainly satisfy the requirements of the defense are exonerated 
history of the insanity defense in the United States is one of persons with legitimate insanity defenses being convicted by jurors in the face of overwhelming evidence of insanity, not the specter of non-insane defendants being acquitted. ${ }^{177}$ The defense is, and always has been, underutilized. ${ }^{178}$ I fear that Slobogin's formulation would lead to a greater underutilization.

My second concern with Slobogin's formulation relates to the defense's potential unavailability to a defendant who "cause[d]" his mental state by "purposely avoiding treatment." ${ }^{179}$ I fear that, if accepted, this caveat could be used broadly and bluntly to suppress the right to refuse the involuntary administration of antipsychotic medication, a right that is otherwise protected by the CRPD as well as by domestic law. ${ }^{180}$ Perhaps the Supreme Court's broadest statement in support of the right to refuse came in the case of Riggins $v$. Nevada, ${ }^{181}$ applying the right in the case of a competent defendant at his insanity-defense trial. ${ }^{182}$ It is significant that the valid and reliable research shows us that jurors believe that defendants who refuse effective medication or therapy are responsible for their impaired mental state at the time of the offense and are therefore blameworthy for their crimes, regardless of what constitutional or statutory provisions may be in place in a jurisdiction at that time. ${ }^{183}$ I fear that Slobogin's formulation would greatly diminish the constitutional scope of the right to refuse. ${ }^{184}$

from what is otherwise culpable criminal behavior."). Also, there is some empirical evidence from other jurisdictions (i.e., Georgia and New York) that revealed that a shift in the burden of proof reduced the rate of insanity pleas in those states. See Perlin, Insanity Defense Jurisprudence, supra note 22, at 100 (citing Henry J. Steadman et aL., Before and After Hinckley: Evaluating Insanity Defense Reform 107-41 (1993)).

177. Michael L. Perlin, "She Breaks Just Like a Little Girl": Neonaticide, the Insanity Defense, and the Irrelevance of "Ordinary Common Sense," 10 WM. \& MARY J. Women \& L. 1, 2-3 (2003) [hereinafter Perlin, Neonaticide]; Michael L. Perlin, The Hidden Prejudice: Mental Disability on Trial $237-38$ (2000) [hereinafter Perlin, Hidden Prejudice].

178. The assumption that the defense is overused is flatly wrong:

A broad-based examination of insanity defense cases demonstrates, beyond any doubt, that when jurors err, they are globally more likely to commit the error of the false negative: overwhelmingly, they reject the insanity defense in cases of defendants who authentically should have been found to have met the standard for criminal nonresponsibility.

Perlin, Neonaticide, supra note 177 , at 18 . The insanity defense is used in, at the most, $1 \%$ of felony cases, and is successful about $25 \%$ of the time. Perlin, InSANITy DefEnSE JuRisPrudence, supra note 22, at 108.

179. Slobogin, Eliminating Mental Disability, supra note 25, at 306 (quoting SLobogin, Minding Justice, supra note 159, at 56). It is significant, I think, that Slobogin bracketed this phrase, most likely reflecting, in his own mind, an ambivalence as to whether this portion of his formula would be accepted as part of a new definition.

180. See PERLIN \& CuColo, supra note 3, $\S \S 8-1$ to 8-14.

181. 504 U.S. $127,135-37$ (1992).

182. On how courts construe cases in which insanity pleaders fail to take medication prior to the commission of the act leading to arrest and trial, see, for example, Crawford v. State, 415 S.E.2d 300 (Ga. Ct. App. 1992); People v. Curry, 588 N.E.2d 423 (Ill. App. Ct. 1992); McFarland v. State, 581 So. 2d 1249 (Ala. Crim. App. 1991).

183. Jennifer L. Skeem \& Stephen L. Golding, Describing Jurors' Personal Conceptions of Insanity and Their Relationship to Case Judgments, 7 Psychol. Pub. PoL’y \& L. 561, 609 (2001).

184. On the related question of the involuntary administration of medication in jail and prison settings, see Alan R. Felthous, Enforced Medication in Jails and Prisons: The New Asylums, 8 ALB. Gov'T L. REv. 563 (2015). 
Slobogin points out that the "purposely avoiding treatment" language 185 "would not afford a person with mental disability an excuse if the impairments that led to a lack of mens rea or a belief that force was necessary were caused by the person's failure to sustain mental health treatment." ${ }^{86}$ But, as this language is in the disjunctive, ${ }^{187}$ it would also control the case of a person charged with a nonviolent offense lacking in mens rea. Beyond this, Slobogin cites to the well-accepted doctrine that one cannot plead a defense if one caused the condition of one's excuse, using the examples of "abus[ing] psychoactive substances or knowingly plac[ing] themselves in harm's way." ${ }^{188}$ But there is a world of difference-both legal difference and "real life" difference-between these examples and the example of one who wishes to assert an otherwise constitutionally protected right to refuse the involuntary administration of antipsychotic medications. ${ }^{189}$ Slobogin concludes that " $[\mathrm{t}] \mathrm{he}$ Convention on the Rights of Persons with Disabilities is a groundbreaking document[ that, t]aken seriously, ... should revolutionize laws that govern people with mental disability." ${ }^{190}$ But I believe that the revolution that might be driven by these General Comment recommendations is the wrong one, and one that should be avoided at all costs.

The most prominent disability-rights advocate who has enthusiastically endorsed the views discussed here is Tina Minkowitz, President and founder of the Center for the Human Rights of Users and Survivors of Psychiatry, and the representative of World Network of Users and Survivors of Psychiatry in the CRPD drafting process. ${ }^{191}$ Minkowitz - who connects her opposition to the insanity defense to her opposition to forensic psychiatry and to TJ-argues that "the

On the international human-rights implications of such drugging, see CTR. FOR HuMAN RIGHTS \& HuMANITARIAN LAW, supra note 4, at 143.

185. See supra note 179 and accompanying text.

186. Slobogin, Eliminating Mental Disability, supra note 25, at 306.

187. Id. ("A person shall be excused for an offense if, at the time of the offense, he or she (a) lacked the subjective mental state for the conduct, circumstance, or result element of the crime; (b) believed circumstances existed that, if true, would have justified the offense; (c) believed circumstances existed that, if true, would have amounted to duress; provided that he or she did not cause any of these mental states [by, inter alia, purposely avoiding treatment, aware that such states would occur without such treatment]." (alteration in original)).

188. See id. But see Commonwealth v. Shin, 16 N.E.3d 1122, 1128 (Mass. App. Ct. 2014) (stating that even if defendant knows that discontinuing medication may result in the subsequent commission of crimes, that decision does not deprive him of the ability to claim lack of substantial capacity).

189. See, e.g., Michael L. Perlin, Keri K. Gould \& Deborah A. Dorfman, Therapeutic Jurisprudence and the Civil Rights of Institutionalized Mentally Disabled Persons: Hopeless Oxymoron or Path to Redemption?, 1 PSYCHOL. PUb. POL'Y \& L. 80, 111 (1995). This may be because of side effects, interference with mentation, impact to meaningfully consult with counsel, or other legally valid reasons. On the significance of the drugs' potential impact on the right to participate in one's defense, see Riggins v. Nevada, 504 U.S. 127, 144 (1992).

190. Slobogin, Eliminating Mental Disability, supra note 25, at 319

191. See generally Michael L. Perlin, "I Might Need a Good Lawyer, Could Be Your Funeral, My Trial": Global Clinical Legal Education and the Right to Counsel in Civil Commitment Cases, 28 WASH. U. J.L. \& POL'Y 241, 261 (2008) ("Although there is a robust 'psychiatric survivor' movement both in the United States and elsewhere, this voice is typically ignored." (citing Peter Margulies, The Cognitive Politics of Professional Conflict: Law Reform, Mental Health Treatment Technology, and Citizen Self-Governance, 5 HARV. J.L. \& TECH. 
capacity to be held accountable for harm done to others or to the community [is] a corollary of the capacity to exercise rights, assume obligations and create legal relationships." 192 She concludes that the insanity defense is contrary to Article 12 of the CRPD "because it undermines the equal recognition of persons with disabilities before the law as individuals with mutual obligations towards others and an equal right to participate in defining and negotiating those obligations." 193

I agree with Minkowitz that the insanity defense, as currently utilized, is often "legally and socially stigmatizing," that insanity acquittals often do not result in release from custody, and that insanity acquittees are often held in forensic facilities for longer than is warranted by the underlying crimes with which they were charged. ${ }^{194}$ And I agree fully that, historically, many of those who have been found not guilty by reason of insanity were the victims of grossly inadequate counsel. ${ }^{195}$ The example of Michael Jones, who was locked up for decades following an insanity acquittal on a charge of attempted shoplifting, ${ }^{196}$ is one of the saddest examples of this reality. ${ }^{197}$

But to say that these realities should lead us to abolish the insanity defense not only throws out the baby with the bathwater, but also throws out the tub and the entire plumbing system as well. I support the insanity defense because I believe that exculpation of some individuals based on mental state is essential to a mature and coherent system of criminal law. It is not the insanity defense that causes the abuses that Minkowitz correctly catalogues, but rather the administration of the post-insanity-defense-acquittal case disposition and institutionalization system. ${ }^{198}$ That is where our attention should be focused.

By way of example, Carole Petersen, noting that it is doubtful that legislatures would ever accept Minkowitz's (or even Slobogin's) position, ${ }^{199}$ thoughtfully argues that it would be "more prudent to propose reforms to the current defenses,

25,56 n. 132, 57-58 (1992))). For an interactionist model of the psychiatric-survivor movement, see Laura Guidry-Grimes, Modelling Psychiatric Disability, 21 J. Evaluation Clinical Prac. 490 (2015).

192. Minkowitz, Some Thoughts, supra note 16.

193. Minkowitz, Rethinking Criminal Responsibility, supra note 16, at 447 . Minkowitz does not discuss whether there are other special considerations at play in the cases of defendants with intellectual disabilities. On the differences in how competency should be assessed in cases of persons with intellectual disabilities and persons with mental illnesses (and on the legal system's failure to differentiate between these conditions), see, for example, Haleigh Reisman, Competency of the Mentally Ill and Intellectually Disabled in the Courts, 11 J. HEALTH \& BiOMEdiCAL L. 199 (2015).

194. Minkowitz, Some Thoughts, supra note 16; see also Perlin, InSANity DefEnSE Jurisprudence, supra note 22 , at $110-11$.

195. Minkowitz, Some Thoughts, supra note 16; see PERLIN, SHAME, supra note 157, at 123-34.

196. See Perlin, Misdemeanor Outlaw, supra note 10, at 213 n.133.

197. On how sanism globally infects the representation of persons with mental disabilities, see Michael L. Perlin \& Alison J. Lynch, "Mr. Bad Example": Why Lawyers Need to Embrace Therapeutic Jurisprudence to Root out Sanism in the Representation of Persons with Mental Disabilities, 16 WYO. L. REv. 299 (2016).

198. Id.

199. But see Cruse v. Florida, 588 So. 2d 983, 989 (Fla. 1991). Cruse affirmed a conviction in which this charge - very much like Slobogin's suggested language — was used: 
providing stronger safeguards and more regular review of detention orders for defendants who are either deemed unfit for trial or relied upon disability-based defenses." 200 The Krol case, in New Jersey, gives us a blueprint as to how these reviews can and should take place. ${ }^{201}$ It is a tragedy that this blueprint has not been embraced by other jurisdictions.

I have found little in Minkowitz's work that deals with the reality that I think we all must focus on in this discussion: what will happen to this cadre of defendants if there is no insanity defense? Elsewhere, Minkowitz does note her opposition to the Standard Minimum Rules for the Treatment of Prisoners. These Rules are a non-binding declaration that has been widely used as an international normative standard for prison management and policy, and that provides that "persons who are found to be insane shall not be detained in prisons and arrangements shall be made to remove them to mental institutions as soon as possible," noting that "the disability community and the Special Rapporteur on Torture have urged deletion of this rule." 202 There are two important issues to consider. First, there is no evidence that "the disability community" as a whole is in agreement on this position. Second, there is no question in my mind that the immediate result of the abolition of the insanity defense would be the long-term incarceration of the population in question in prisons that we know are dangerous and life-threatening to this population. $^{203}$

\begin{abstract}
A person may be legally sane in accordance with the instructions previously given and still yet, by reason of mental infirmity, have hallucinations or delusions which cause him to honestly believe to be facts things which are not true or real. The guilt of a person suffering from such hallucinations or delusions is to be determined just as though the hallucinations or delusions were actual facts. If the act of the defendant would have been lawful had the hallucinations or delusions been the actual facts, the defendant is not guilty of the crime.
\end{abstract}

Id.

200. Carole J. Petersen, Addressing Violations of Human Rights in Forensic Psychiatric Institutions: Philosophical and Strategic Debates, Remarks Before the American Society of International Law (2015), in 109 American Society of International LaW, Proceedings of the Annual Meeting 82 (2015).

201. See Perlin \& CuCOlO, supra note $3, \S 14-2.1 .1$. The court in Krol read the U.S. Supreme Court cases of Jackson v. Indiana, 406 U.S. 715 (1972), and Baxstrom v. Herold, 383 U.S. 107 (1966), as "plainly attempt[ing] to enunciate a broad principle - that the fact that the person to be committed has previously engaged in criminal acts is not a constitutionally acceptable basis for imposing upon him a substantially different standard or procedure for involuntary commitment," and stated that "the labels 'criminal commitment' and 'civil commitment' are of no constitutional significance." Krol, 344 A.2d at 297. On how Krol "provid[ed] expanded procedural due process rights for insanity acquittees," see Perlin, Misdemeanor Outlaw, supra note 10, at 195 n.15.

202. Minkowitz, Rethinking Criminal Responsibility, supra note 16, at 436.

203. Interestingly, when Montana abolished its insanity defense, researchers demonstrated that there was a concomitant, statistically significant increase in the number of defendants found permanently incompetent to stand trial, and that the state housed those defendants in the same facilities where it previously housed insanity acquittees. See Perlin, Borderline, supra note 95, at 1423 n.316 (discussing research reported in Rita D. Buitendorp, A Statutory Lesson from "Big Sky Country" on Abolishing the Insanity Defense, 30 VAL. U. L. REV. 965, 993-96 (1996), and in Steadman et al., supra note 147, at 359-60). But, of course, Montana did not abolish (nor could it have abolished) the incompetency status. One partial solution would be to improve the quality of life in prisons. But the reports done by Human Rights Watch and other similar groups, discussed earlier in this Article, 
I see no consideration of the realities of seriously mentally ill defendantsimprisoned because of the absence of a non-responsibility defense-in Minkowitz's writings, and it is her failure to address this that concerns me the most. ${ }^{204}$

\section{Treatment of Persons with Mental Disabilities in Prisons}

It is necessary to focus on what happens to persons with mental disabilities when they are imprisoned. A recent exhaustive report erases any shred of doubt that persons with mental disabilities are regularly brutalized and tortured in prison settings. ${ }^{205}$ First, there is no dispute that "most jails and prisons do not conform to nationally accepted guidelines for mental health screening and treatment." 206 As a group, persons with mental disabilities are frequently and disproportionally the victims of violence and abuse inside correctional settings. ${ }^{207}$ In this context, sexual victimization is a significant concern for incarcerated people, "particularly those with mental disabilities." 208

This is a reality that must be acknowledged in any conversation about the CRPD or the abolition of the insanity defense and incompetency status. In its report, "Callous and Cruel: Use of Force Against Inmates with Mental Disabilities in US

suggest that this would be nearly impossible. An alternative would be to seek diversion from prisons to community mental-health systems. See, e.g., Megan Testa, Imprisonment of the Mentally Ill: A Call for Diversion to the Community Mental Health System, 8 ALb. Gov'T L. Rev. 405 (2015). See generally Terry A. Kupers, A Community Mental Health Model in Corrections, 26 StAN. L. \& POL'y Rev. 119 (2015).

204. There is evidence that in many jurisdictions, including some states in Australia, a person who is found unfit or not guilty because of insanity will be imprisoned because there are no alternative facilities. See Girard Dorney, Prisons Are Acting as De Facto Mental Health Facilities for Indigenous Australians, VICE (Apr. 30, 2015, 8:00 PM), https://www.vice.com/en_us/article/a-look-at-indigenous-mental-health-inside-australias-prisonsystem. Significantly, this happens mostly in those states (i.e., Northern Territory and Western Australia) that have the largest indigenous populations.

In Albania, persons with mental disabilities who have been charged with a criminal offense reside in a prison unit and must comply with prison rules while institutionalized. Michael L. Perlin, International Human Rights Law and Comparative Mental Disability Law: The Universal Factors, 34 SyRACUSE J. INT'L L. \& COM. 333, 354 (2007) (citing Harvey Weinstein, Ira Burnim \& Robert Okin, Protecting the Mentally Disabled, CARNEGIE Council (May 6, 2001), http://www.carnegiecouncil.org/publications/archive/dialogue/2_06/online_exclusive/ 654.html). I am also concerned that this debate will, in Paul Appelbaum's perceptive words, "distract attention from the positive changes that the convention could make for the rights of persons with disabilities." Appelbaum, supra note 31 , at 368 .

205. See generally E. Lea Johnston, Vulnerability and Just Desert: A Theory of Sentencing and Mental Illness, 103 J. CRIm. L. \& CRIminology 147 (2013) ("[O]ffenders with serious mental illnesses are more likely than non-ill offenders to suffer physical and sexual assaults ...."); E. Lea Johnston, Conditions of Confinement at Sentencing: The Case of Seriously Disordered Offenders, 63 CATH. U. L. REv. 625 (2014) (same). For a state example, see Jonathan D. LeCompte, When Cruel Becomes the Usual: The Mistreatment of Mentally Ill Inmates in South Carolina Prisons, 66 S.C. L. REv. 751 (2015).

206. Henry A. Dlugacz, Correctional Mental Health in the USA, 10 InT'L J. Prisoner Health 3, 10 (2014) (citing Steven K. Hoge et al., Am. Psychiatric Ass'n, Outpatient Services for the Mentally Ill Involved in the Criminal Justice System (2009)).

207. Dlugacz, supra note 206, at 10 (citing Michael L. Perlin \& Henry A. Dlugacz, "It's Doom Alone that Counts": Can International Human Rights Law Be an Effective Source of Rights in Correctional Conditions Litigation?, 27 BeHAV. SCI. \& L. 675 (2009); Dlugacz \& Wimmer, supra note 57, at 362-63).

208. $I d$. 
Jails and Prisons," Human Rights Watch ("HRW") charged that jail and prison staff regularly use "unnecessary, excessive, or malicious . . f force against prisoners with mental disabilities." 209 The report concludes:

Corrections officials at times needlessly and punitively deluge them with chemical sprays; shock them with electric stun devices; strap them to chairs and beds for days on end; break their jaws, noses, ribs; or leave them with lacerations, second degree burns, deep bruises, and damaged internal organs. The violence can traumatize already vulnerable men and women, aggravating their symptoms and making future mental health treatment more difficult. In some cases, including several documented in this report, the use of force has caused or contributed to prisoners' deaths. ${ }^{210}$

Jamie Fellner, author of the report and U.S. program senior adviser at HRW, concludes that such facilities "can be dangerous, damaging, and even deadly places for men and women with mental health problems." 211 The report identified policies and practices that led to unwarranted force, based on a review of hundreds of individual court cases, class-action cases, and Justice Department investigations, and based on interviews with more than 125 current and former corrections officials, use-of-force experts, psychiatrists, and prisoner advocates. ${ }^{212}$

This report offers multiple recommendations: (1) public officials should reduce the number of prisoners with mental disabilities confined in prisons and jails, including by increasing the availability of community mental-health resources and access to criminal-justice diversion programs; (2) officials should also improve mental-health services in prisons and jails and ensure that correctional facilities adopt and follow sound policies on using force that consider the unique needs and vulnerabilities of prisoners with mental illness; ${ }^{213}$ and (3) officials should use training to enforce these policies and include mechanisms for holding accountable staff who violate them. ${ }^{214}$

These recommendations should not be surprising to anyone who follows developments in this area. At the outset, "there is no evidence that prisoners with psychiatric disabilities are receiving constitutionally adequate treatment." ${ }^{215}$ Prison

209. United States: Force Against Prisoners with Mental Illness, Hum. RTs. WATCH 4 (May 12, 2015, 12:00 AM) [hereinafter HRW, Force], https://www.hrw.org/news/2015/05/12/united-states-force-against-prisonersmental-illness. On how such cruel treatment has become "usual" in this context, see LeCompte, supra note 205.

210. Callous and Cruel, Hum. RTs. WATCH 2 (May 12, 2015) [hereinafter HRW, Cruel], https://www.hrw.org/ report/2015/05/12/callous-and-cruel/use-force-against-inmates-mental-disabilities-us-jails-and.

211. HRW, Force, supra note 209, at 2.

212. HRW, Cruel, supra note 210 , at 7.

213. For a therapeutic-based analysis of the requirement that correctional staff and facilities provide special protection to vulnerable inmates such as those discussed here, see Warren Brookbanks, Therapeutic Jurisprudence and Its Role in Corrections, in Therapeutic Jurisprudence: New Zealand Perspectives 163, 170-71 (Warren Brookbanks ed., 2015).

214. New Zealand has taken steps to implement such policies. See id.

215. Simon \& Rosenbaum, supra note 80 , at $43-44$. 
sentences violate the Eighth Amendment when they continue past the point where further incarceration will deepen the prisoner's psychiatric disabilities. ${ }^{216}$ In Brown v. Plata, ${ }^{217}$ the Supreme Court relied on language it used in a prison-medicalcare case from forty years ago in finding that a prison's failure to provide adequate mental-health care may produce torture. ${ }^{218}$ About $30 \%$ of inmates in solitary confinement are mentally ill. ${ }^{219}$ Remarkably, the average solitary-confinement sentence for New York inmates with mental illness is also six times longer than that of the general inmate population, ${ }^{220}$ and there is robust evidence that solitary confinement is used disproportionately in cases involving victims of sexual assault by prison guards. ${ }^{221}$ The use of solitary confinement in such cases is inevitably counterproductive. ${ }^{222}$ Prisoners with mental-health problems serve longer than prisoners convicted of like offenses without such problems, and only about one-third of all prisoners with mental-health problems receive treatment while

\footnotetext{
216. See Madrid v. Gomez, 889 F. Supp. 1146, $1244-45,1258-59$ (N.D. Cal. 1995). On settings, see Felthous, supra note 184 (discussing the administration of enforced medication in non-medical correctional facilities, and recommending that individuals receive enforced medication in mental hospitals).
}

217. 563 U.S. 493 (2011). See generally Henry Dlugacz \& Christopher Wimmer, Le gal Aspects of Administering Antipsychotic Medications to Jail and Prison Inmates, 36 INT'L J.L. \& PsYCHIATRY 213 (2013) (discussing the legal standards regarding informed consent and forcible administration of medication in correctional institutions).

218. Brown, 563 U.S. at 510 ("To incarcerate, society takes from prisoners the means to provide for their own needs. Prisoners are dependent on the State for food, clothing, and necessary medical care. A prison's failure to provide sustenance for inmates 'may actually produce physical "torture or a lingering death."," (quoting Estelle v. Gamble, 429 U.S. 97, 103 (1976))).

219. Jessica Knowles, "The Shameful Wall of Exclusion": How Solitary Confinement for Inmates with Mental Illness Violates the Americans with Disabilities Act, 90 WASH. L. REv. 893, 907 (2015) (citing ACLU NAT'L Prison Project, aClu Briefing Paper: The Dangerous Overuse of Solitary Confinement in the United States 6 (2013)). See generally Elizabeth Alexander, "This Experiment, So Fatal": Some Initial Thoughts on Strategic Choices in the Campaign Against Solitary Confinement, 5 U.C. IRvinE L. REv. 1 (2015) (discussing isolated confinement in America and litigation challenges to the practice). Similar findings have been made in European studies. See Stuart Grassian, Psychiatric Effects of Solitary Confinement, 22 WASH. U. J.L. \& POL'Y 325,342 (2006) (discussing the exacerbation of existing mental conditions that results from solitary confinement); Henrik Steen Andersen, Mental Health in Prison Populations: A Review - with Special Emphasis on a Study of Danish Prisoners on Remand, 110 ACTA Psychiatrica SCANDinaviCa SupPlementum 5, 50 (2004) (discussing the prevalence of mentally ill individuals in solitary confinement and in prisons generally). For a relevant historical overview, see Michael B. Mushlin, "I Am Opposed to this Procedure": How Kafka's In the Penal Colony Illuminates the Current Debate About Solitary Confinement and Oversight of American Prisons, 93 OR. L. REv. 571 (2015). This is to say not that all these prisoners should have been found not guilty by reason of insanity (though, certainly, some should have, see sources cited supra note 151), but rather that the elimination of the insanity defense will make this wretched situation even worse.

220. Knowles, supra note 219, at 896 (citing Hum. RTs. Watch, Ill-EquipPed: U.S. PRIsOns and Offenders With Mental IlLness 147, 147-48 (2003)). In her article, Knowles argues that American solitary-confinement policies violate the Americans with Disabilities Act ("ADA"). Id. at 893-94; see also Mary T. Zdanowicz, Keeping the Mentally Ill out of Jail: Sheriffs as Litigants, 8 ALB. Gov'T L. REv. 536, 537 (2015) (discussing the ADA as a potential litigation tool); Alexander, supra note 219, at 33-34 (same).

221. Kim Shayo Buchanan, Impunity: Sexual Abuse in Women's Prisons, 42 HARv. C.R.-C.L. L. REv. 45, 66 (2007).

222. Bandy X. Lee \& Maya Prabhu, A Reflection on the Madness in Prisons, 26 Stan. L. \& Pol'y Rev. 253, $259-60$ (2015). 
imprisoned. ${ }^{223}$ Half of all prison suicides are committed by persons with serious mental illness. ${ }^{224}$ The abolition of the insanity defense and the incompetency status-leading directly to more persons with serious mental illnesses being imprisoned - will inevitably increase these abysmal rates.

This problem is not limited to the United States. The treatment of aboriginal individuals with mental disabilities in Australian prisons is a national scandal. ${ }^{225} \mathrm{~A}$ significant number of aboriginal people with cognitive impairment are currently being held in maximum-security prisons, despite not having been convicted of or sentenced for a crime that would require them to be held in such facilities. ${ }^{226}$ Studies of Canadian prisons indicate that heightened use of solitary confinement further isolates persons with mental disabilities. ${ }^{227}$ Anyone who has worked "on the ground" in the general correctional setting knows that many guards believe that this cohort of defendants is merely feigning and manipulative, and those guards thus seek to punish them for "gaming the system." "228 This is another aspect of institutional sanism. ${ }^{229}$

Persons with mental disabilities are especially stigmatized in prison settings; the disability becomes the stigma. ${ }^{230}$ Sanism is especially pernicious in institutional

223. Doris J. James \& Lauren E. Glaze, Bureau of Justice Statistics, Mental Health Problems of PRISON AND JAIL INMATES 9 (2006).

224. Kanya D'Almeida, In US Prisons, Psychiatric Disability Is Often Met by Brute Force, Truthout (July 18, 2015, 12:00 AM), http://www.truth-out.org/news/item/31886-in-us-prisons-psychiatric-disability-is-often-metby-brute-force\#.

225. See, e.g., Aboriginal Disability Justice Campaign, People with Disablity, http://www.pwd.org.au/adjc/ about-us-adjc.html (last visited Nov. 13, 2016). See generally Mindy SOTIRI ET AL., Aboriginal Disabllti Justice Campaign, No End in Sight: The Imprisonment, and Indefinite Detention of Indigenous AustraLIANS WITH A COGNITIVE IMPAIRMENT 7 (2012) (discussing the overrepresentation of indigenous Australians with cognitive impairment in the criminal-justice system). One study has found that the overall incidence of psychiatric disorder for Australian prisoners has reached $80 \%$. See Tony Butler et al., Mental Disorders in Australian Prisoners: A Comparison with a Community Sample, 40 AuSTL. \& N.Z. J. PsyChIATRY 272, 273 (2006).

226. Sotiri ET AL., supra note 225, at 7.

227. Syrus Ware, Joan Ruzsa \& Giselle Dias, It Can't Be Fixed Because It's Not Broken: Racism and Disability in the Prison Industrial Complex, in Disability InCARCERATED: IMPRISONMENT AND DiSABILITY IN THE UNITED States ANd CANADA 163, 168 (Liat Ben-Moshe et al. eds., 2014).

228. E-mail from Henry A. Dlugacz, Esq., to author (Aug. 8, 2015, 11:06 AM) (on file with author). Dlugacz's law practice focuses on "mental health-related matters, with a particular emphasis on the monitoring and mediation of complex class action lawsuits involving correctional systems of treatment, forensic hospitals, reentry planning, and community-based systems." Henry Dlugacz, Beldock Levine \& HofFman LLP, http://www.blhny.com/\#!henry-dlugacz/cevk (last visited Nov. 19, 2016). On how prison guards exercise institutional control in Norway, see Alexander Z. Ibsen, Ruling by Favors: Prisons Guards' Informal Exercise of Institutional Control, 38 L. \& SOC. INQUIRY 342 (2013).

229. See Sasha Abramsky \& Jamie Fellner, Human Rights Watch, Ill-equipped: U.S. Prisons and OFFENDERS WITH MENTAL IlLNESS 106 (2003) ("Security staff, who lack mental health training, are often quick to assume that prisoners are acting volitionally or manipulatively when they act out.").

230. Carrie Griffin Basas \& Lisa Peters, Deprivation and "Deviance": The Disability and Health Experiences of Women in North Carolina's Prisons, 93 N.C. L. Rev. 1223, 1247-48 (2015). 
settings, ${ }^{231}$ and its power in jails and prisons is particularly vicious. ${ }^{232}$ Indeed, there are some who argue that, at least in the cases of juveniles, there should be an entirely separate justice system for mentally ill offenders, modeled after currently existing mental-health courts. ${ }^{233}$ What is most perplexing is that scholars and disability-rights advocates - such as Janet Lord - have focused their attention on the reality that "[just as] poor conditions for detention in prisons . . . may amount to torture or other ill-treatment, practices that involve the use of restraints or seclusion similarly require serious scrutiny under Article 15 [of the CRPD]."234 In short, persons with mental illness are regularly tortured in America's jails and prisons, and we have known this for years. ${ }^{235}$ Lord notes further that "close monitoring of the living conditions of persons with disabilities in prisons and other institutional settings is essential." 236 An influx of an additional population of persons with mental illness-likely far more mentally ill than the "typical" prisoner-will do nothing but exacerbate this level of torture. Tellingly, the abolition of the insanity defense or the incompetency status is not among any of HRW's recommendations.

231. See, e.g., Michael L. Perlin, "Through the Wild Cathedral Evening": Barriers, Attitudes, Participatory Democracy, Professor tenBroek, and the Rights of Persons with Mental Disabilities, 13 TEX. J. ON C.L. \& C.R. 413, 417-18 (2007) (discussing the prevalence of sanism and stereotypes about disability and the need to allow persons with disabilities to participate in society and exercise their legal capacity).

232. On how sanism - "manifested ... by a refusal to take seriously the issues that affect persons with mental disabilities, especially institutionalized persons-is the root cause of [the wholesale violation of human rights of this population]," see Perlin \& Dlugacz, supra note 207, at 688 n. 100.

233. Cf. Mona Sobhani, Extending the Logic of the Juvenile Justice System to a Separate Justice System for Mentally Ill Offenders, 8 ALB. Gov't L. REv. 439, 441 (2015) (applying "the logic of the juvenile justice system to argue for a separate justice system for severely mentally ill offenders"). Importantly, in a recent article, Professor David Katner argued persuasively that the presumption of competency regularly employed in the juvenile justice system should be abandoned and that the party seeking an adjudication should be responsible for establishing that the accused juvenile is in fact competent to stand trial. See David R. Katner, Eliminating the Competency Presumption in Juvenile Delinquency Cases, 24 CORnell J.L. \& Pub. POL'y 403, 403 (2015). The proposed abolition of the incompetency status, of course, flies squarely in the face of Professor Katner's thoughtful suggestion.

On mental-health courts in general, see Michael Perlin, "There Are No Trials Inside the Gates of Eden": Mental Health Courts, the Convention on the Rights of Persons with Disabilities, Dignity and the Promise of Therapeutic Jurisprudence, in CoERcive CARE: RightS, LAW AND POLICY 193 (Bernadette McSherry \& Ian Freckelton eds., 2013) [hereinafter Perlin, No Trials Inside Eden]. This topic is beyond the scope of this paper.

234. Janet E. Lord, Shared Understanding or Consensus-Masked Disagreement? The Anti-Torture Framework in the Convention on the Rights of Persons with Disabilities, 33 LOY. L.A. INT'L \& COMP. L. REv. 27, 60 (2010); see also McSherry \& Gooding, supra note 37, at 712 (discussing U.N. report on the presence of torture and mistreatment throughout different countries' healthcare practices).

235. See, e.g., Avlana K. Eisenberg, Incarceration Incentives in the Decarceration Era, 69 VAND. L. Rev. 71 , 102, 102 n. 177 (2016).

236. Lord, supra note 234 , at 49 . Some advocate how the adoption of a community mental health model might somewhat remediate the current situation. See Terry A. Kupers, A Community Mental Health Model in Corrections, 26 STAN. L. \& POL'Y Rev. 119, 123-25 (2015). 


\section{TherAPEUTIC JuRISPRUDENCE}

How does this all fit with therapeutic jurisprudence? ${ }^{237}$ As TJ "asks us to look at law as it actually impacts people's lives"238 and "focuses on the law's impact on emotional life and psychological well-being,"239 it forces us to look at the "real world" implications of the abolition arguments to determine whether such abolition would be consonant with TJ aims and aspirations.

The ultimate aim of TJ is to determine whether legal rules, procedures, and roles for lawyers can or should be reshaped to enhance their therapeutic potential while not subordinating due-process principles. ${ }^{240}$ There is an inherent tension in this inquiry, but David Wexler clearly identifies how it must be resolved: the law's use of "mental health information to improve therapeutic functioning [cannot] impinge upon justice concerns." 241 It is vital to keep in mind that "an inquiry into therapeutic outcomes does not mean that therapeutic concerns 'trump' civil rights and civil liberties." 242 In its aim to use the law to empower individuals, enhance rights, and promote well-being, TJ has been described as "a sea-change in ethical thinking about the role of law ... a movement towards a more distinctly relational approach to the practice of law ... which emphasise[s] psychological wellness

237. Portions of this section are adapted from Perlin \& Lynch, Sexless Patients, supra note 131, at 277-79; Michael L. Perlin, "John Brown Went off to War": Considering Veterans Courts as Problem-Solving Courts, 37 Nova L. Rev. 445, 452-55 (2013) [hereinafter Perlin, John Brown]; Michael L. Perlin \& Naomi M. Weinstein, "Friend to the Martyr, a Friend to the Woman of Shame": Thinking About the Law, Shame and Humiliation, $24 \mathrm{~S}$. CaL. Rev. L. \& Soc. Just. 1, 9-13 (2014); Michael L. Perlin \& Alison J. Lynch, "Had to Be Held down by Big Police": A Therapeutic Jurisprudence Perspective on Interactions Between Police and Persons with Mental Disabilities, 42 Fordham Urb. L.J. (2017) [hereinafter Perlin \& Lynch, Interactions with Police]. It also distills a significant portion of my work over the past two decades. See, e.g., Michael L. Perlin, What Is Therapeutic Jurisprudence?, 10 N.Y.L. ScH. J. Hum. RTS. 623 (1993).

238. Winick, supra note 24, at 535.

239. Wexler, supra note 24 , at 45 .

240. See Perlin, Role and Significance of Counsel, supra note 24, at 751; Perlin, Sexual Autonomy, supra note 39, at 510 n.139; Perlin, Guardians and Protectors, supra note 27, at 1184; see also Michael L. Perlin, "Baby, Look Inside Your Mirror": The Legal Profession's Willful and Sanist Blindness to Lawyers with Mental Disabilities, 69 Piтt. L. Rev. 589, 591 (2008) (discussing how therapeutic justice may help combat sanism and stigmas associated with mental disorders in the law); Bernard P. Perlmutter, George's Story: Voice and Transformation Through the Teaching and Practice of Therapeutic Jurisprudence in a Law School Child Advocacy Clinic, 17 St. Thomas L. REv. 561, 599 n.111 (2005) (citing Bruce J. Winick, Therapeutic Jurisprudence and the Civil Commitment Hearing, 10 J. CONTEMP. LEGAL IssuEs 37, 46-47 (1999) (discussing how lawyers can help to reform civil commitment hearings to improve patients' perceptions of fairness within such hearings)); Ian Freckelton, Therapeutic Jurisprudence Misunderstood and Misrepresented: The Price and Risks of Influence, 30 T. JEFFERSON L. REV. 575, 585-86 (2008) (discussing the role that TJ should play in judicial decision-making).

241. See David B. Wexler, Therapeutic Jurisprudence and Changing Conceptions of Legal Scholarship, 11 Behav. Sci. \& L. 17, 21 (1993); David B. Wexler, Applying the Law Therapeutically, 5 Applied \& Preventive PSYCHOL. 179, 185 (1996).

242. Michael L. Perlin, A Law of Healing, 68 Cin. L. Rev. 407, 412 (2000) [hereinafter Perlin, Law of Healing]; Perlin, Us and Them, supra note 98, at 782. 
over adversarial triumphalism." 243 That is, TJ supports an ethic of care. ${ }^{244}$

One of the central principles of TJ is a commitment to dignity. ${ }^{245}$ No explanation of how the legal process should implement TJ is better than Professor Amy Ronner's description of the "three Vs": voice, validation, and voluntariness. ${ }^{246}$ She argues the following:

What "the three Vs" commend is pretty basic: litigants must have a sense of voice or a chance to tell their story to a decision maker. If that litigant feels that the tribunal has genuinely listened to, heard, and taken seriously the litigants [sic] story, the litigant feels a sense of validation. When litigants emerge from a legal proceeding with a sense of voice and validation, they are more at peace with the outcome. Voice and validation create a sense of voluntary participation, one in which the litigant experiences the proceeding as less coercive. Specifically, the feeling on the part of litigants that they voluntarily partook in the very process that engendered the end result or the very judicial pronunciation that affects their own lives can initiate healing and bring about improved behavior in the future. In general, human beings prosper when they feel that they are making, or at least participating in, their own decisions. ${ }^{247}$

Is the abolition of the insanity defense and the incompetency status consonant with or dissonant with TJ? I believe that the positions that I staked out on these questions fifteen years ago are still the correct ones - that, in the context of TJ: (1) the insanity defense is therapeutic; ${ }^{248}(2)$ the substantive standard and procedural rules matter; ${ }^{249}$ (3) current post-acquittal rules that follow the U.S. Supreme

243. Warren Brookbanks, Therapeutic Jurisprudence: Conceiving an Ethical Framework, 8 J.L. \& MED. 328 , 329-30 (2001); see also Bruce J. Winick, Overcoming Psychological Barriers to Settlement: Challenges for the TJ Lawyer, in The Affective Assistance of Counsel: Practicing Law as a Healing Profession 341 (Marjorie A. Silver ed., 2007) (discussing the role of lawyers as therapeutic agents when representing clients); Bruce J. Winick \& David B. Wexler, The Use of Therapeutic Jurisprudence in Law School Clinical Education: Transforming the Criminal Law Clinic, 13 CLINICAL L. REv. 605, 605-06 (2006) (discussing the rise of TJ as a new form of lawyering that incorporates planning and sensitivity). See generally Carol Gilligan, IN A DIFFERENT Voice: Psychological Theory and Women's Development (1982) (discussing the phrase "therapeutic jurisprudence").

244. See Gregory Baker, Do You Hear the Knocking at the Door? A "Therapeutic" Approach to Enriching Clinical Legal Education Comes Calling, 28 WhitTer L. Rev. 379, 385 (2006); Brookbanks, supra note 243; David B. Wexler, Not Such a Party Pooper: An Attempt to Accommodate (Many of) Professor Quinn's Concerns About Therapeutic Jurisprudence Criminal Defense Lawyering, 48 B.C. L. REv. 597, 599 (2007); Winick \& Wexler, supra note 243, at 605-07.

245. See Bruce J. Winick, Civil Commitment: A Therapeutic Jurisprudence Model 161 (2005).

246. Ronner, supra note 40, at 627; see also Freckelton, supra note 240, at 588 (discussing the importance of "voice").

247. Amy D. Ronner, Songs of Validation, Voice, and Voluntary Participation: Therapeutic Jurisprudence, Miranda and Juveniles, 71 CIN. L. REv. 89, 94-95 (2002) (footnotes omitted); see also Simon \& Rosenbaum, supra note 80 , at 35-37 (discussing the significance of voice in a TJ context in the related area of civil commitment law).

248. Perlin, Hidden Prejudice, supra note 177, at 289-95.

249. Id. at $295-97$. 
Court's dictates in Jones v. United States are anti-therapeutic, ${ }^{250}$ and (4) TJ principles must be more rigorously applied to issues involving post-acquittal institutionalization and community monitoring. ${ }^{251}$

We must rigorously apply $\mathrm{TJ}$ principles to each aspect of the insanity defense. We need to take what we learn from TJ to strip away sanist behavior, pretextual reasoning, and teleological decision-making from the insanity-defense process. This would enable us to confront the pretextual use of social-science data in an open and meaningful way. ${ }^{252}$

I have been critical of the ways that insanity acquittee release and recommitment hearings have been conducted on issues ranging from the lack of adequate counsel, to judges' perfunctory treatment of these matters, to the sanism and pretext reflected in the positions of prosecutors in their efforts to oppose lessening restraints or changing conditions of confinement or release. ${ }^{253}$ But, as I noted above, it is not the insanity defense that causes these abuses, but rather the administration of the post-insanity-defense-acquittal case disposition and institutionalization system. $^{254}$

So, if there is to be no insanity defense, then there will be no insanity-acquittal release and recommitment hearings, as the cohort of defendants in question will be in prison.

Scholars and practitioners, writing in the context of civil-commitment hearings, have argued that that process had great therapeutic potential, reasoning that such hearings are therapeutic because (1) they give patients an opportunity to present and hear evidence in a meaningful court procedure, ${ }^{255}$ and (2) they can increase the likelihood that any subsequent hospitalization and treatment will be successful. ${ }^{256}$

This aligns perfectly with concepts of procedural justice, developed initially by Tom Tyler and validated in empirical tests by Tyler and other researchers. ${ }^{257}$ Certainly, there is no reason to assume that this would be less likely to apply to

250. Id. at 297-99; see Perlin, Law of Healing, supra note 242, at 430 n.157.

251. Perlin, Hidden Prejudice, supra note 177, at 299-300.

252. Id. at 443 .

253. See, e.g., Perlin, Misdemeanor Outlaw, supra note 10, at 236. See generally Perlin, Borderline, supra note 95; Perlin, Insanity Defense Jurisprudence, supra note 22.

254. See supra text accompanying note 198.

255. Perlin, Role and Significance of Counsel, supra note 24, at 742 (citing John J. Ensminger \& Thomas D. Liguori, The Therapeutic Significance of the Civil Commitment Hearing: An Unexplored Potential, 6 J. PsYCHIATRY \& L. 5, 8 (1978)).

256. Charles J. Kennedy, Judicial Behavior and the Civil Commitment Petitioner, in JudGing IN A THERAPEUTIC Key: Therapeutic Jurisprudence and the Courts 159-63 (Bruce J. Winick \& David B. Wexler eds., 2003).

257. E.g., Tom R. Tyler, The Psychological Consequences of Judicial Procedures: Implications for Civil Commitment Hearings, 46 SMU L. Rev. 433, 443 (1992); Michele Cascardi, Norman G. Poythress \& Alicia Hall, Procedural Justice in the Context of Civil Commitment: An Analogue Study, 18 BeHAV. SCI. \& L. 731, 738-39 (2000). See generally PerLin, Prescription fOr Dignity, supra note 84 (discussing the general relationship between procedural justice and TJ). 
cases involving insanity acquittees. But again, if the defense is abolished, then so are these hearings.

On the question of whether the defense is consonant with $\mathrm{TJ}$ principles, consider the words of the late Judge David Bazelon: "By declaring a small number not responsible, we emphasize the responsibility of all others who commit crimes."258 Judge Bazelon concluded, in other words, that "the existence of the insanity defense gives coherence to the entire fabric of criminal sentencing." 259 By punishing defendants who are not responsible, "we diminish all the rationales for punishment of the others whom we believe to be responsible for their crimes."260

Indeed, in Clark v. Arizona, ${ }^{261}$ which held that a state's insanity test that was couched solely in terms of capacity to tell whether an act is right or wrong did not violate due process, ${ }^{262}$ the Supreme Court came perilously close to condoning the punishment of such non-responsible defendants. In criticizing that decision, I have said:

Almost 25 years ago, Judge David Bazelon, writing in the American Psychologist, argued that the courts should "open the courthouse doors" to mental health professionals, warning that they should "never hand over the keys.",263 They may now not be slammed shut, but it is fair to say that after Clark, Judge Bazelon's dreams have now been, for the foreseeable future, dashed. ${ }^{264}$

Certainly, the abolition of the insanity defense would both slam the door shut and throw away the key. ${ }^{265}$

This becomes even more crucial when we consider the ways that individuals with mental disabilities are treated in prisons. The description of an expert witness in a prison double-celling case from twenty-five years ago - noting that "doublecelling" inmates with mental disabilities with non-disabled inmates in administrative segregation was a practice akin to "putting the chickens in the fox's lair" 266 - is yet another reminder of the sad reality of what happens to this population in such settings. ${ }^{267}$

258. Perlin, Hidden Prejudice, supra note 177, at 293 (quoting David L. Bazelon, Questioning Authority: Justice ANd CRiminal Law 2 (1988)).

259. $I d$.

260. Id. at 293-94.

261. Clark v. Arizona, 548 U.S. 735 (2006).

262. Id. at 742 .

263. David L. Bazelon, Veils, Values, and Social Responsibility, 37 Aм. Psychologist 115, 115 (1982).

264. Perlin \& Cucolo, supra note $3, \S 14-1.2 .8$.

265. Beyond the scope of this Article is an analysis of the application of TJ to correctional facilities. See, e.g., Astrid Birgden, A Compulsory Drug Treatment Program for Offenders in Australia: Therapeutic Jurisprudence Implications, 30 T. JEFFERSON L. REv. 367, 386-87 (2008); sources cited supra note 240.

266. Tillery v. Owens, 907 F.2d 418, 424-25 (3d Cir. 1990).

267. For the earliest TJ-based analysis of the mental-healthcare needs of prisoners, see generally Fred Cohen \& Joel A. Dvoskin, Therapeutic Jurisprudence and Corrections: A Glimpse, 10 N.Y.L. SCH. J. Hum. RTs. 777, 784 (1993). 
The need to retain the incompetency status is even more pressing in the cases of criminal defendants with mental disabilities. Keri Gould, Deborah Dorfman, and I have concluded that " $[\mathrm{t}]$ he perception of receiving a fair hearing is therapeutic because it contributes to the individual's sense of dignity and conveys that he or she is being taken seriously." 268 A defendant who cannot cooperate with his counsel, who cannot understand the proceedings, will have no sense of dignity and will not be taken seriously by the finder of facts or anyone else in the courtroom.

Tellingly, Minkowitz disparages TJ, alleging that it is "another variety of therapy to be imposed on the person without his or her free and informed consent." ${ }^{269}$ There is not a shred of evidence in the TJ literature-indeed, she cites none $^{270}$ - supporting this position. Elsewhere, she argues that from the perspective of a psychiatric-abuse survivor, "it is a concept to avoid," claiming that it constitutes "handing over justice issues to professions (or even to a conceptual framework associated with those professions) that have repeatedly violated trust and perpetrated torture with drugs and electroshock and mind games of dominance and control.",271

I am utterly puzzled by this misstatement of what TJ is supposed to mean. There are those who wrap themselves in the mantle of TJ while acting in ways that are dissonant with TJ's principles and aspirations. There are certainly many judges who, seeing themselves as "adjunct therapists," inappropriately trample upon due-process rights in their quest to "do good." 272 I believe that the TJ community needs to be more vigilant in "calling out" such rogue behavior. ${ }^{273}$ An excellent starting point is Professor Ida Dickie's discussion of how a TJ emphasis on procedural fairness and respect for autonomy can help all stakeholders in the criminal-justice system. ${ }^{274}$

268. Perlin, Gould \& Dorfman, supra note 189, at 114.

269. Minkowitz, Rethinking Criminal Responsibility, supra note 16, at 438

270. Her only citation here is to a conversation that she had with a mental-health-rights lawyer some thirteen years ago.

271. Minkowitz, Some Thoughts, supra note 16.

272. See Perlin, John Brown, supra note 237, at 449 (criticizing certain problem-solving courts that do not follow TJ principles as "existing instead in a due process-free zone-implicitly rejecting the basic TJ "premise that therapeutic outcomes cannot trump due process"' (quoting Perlin, No Trials Inside Eden, supra note 233, at 207)).

273. See Eleanore Fritze, Shining a Light Behind Closed Doors: Report of the Jack Brockhof Foundation Churchll Fellowship to Better Protect the Human Rights and Dignity of People with Disablities, Detained in Closed Environments for Compulsory Treatment, Through the Use of InnovaTIVE LeGaL SERVices 51-54 (2015).

274. Ellen Waldman, Therapeutic Jurisprudence: Growing up and Looking Forward, 30 T. JEFFERson L. Rev. 345, 347 (2008) (discussing Ida Dickie, Ethical Dilemmas, Forensic Psychology, and Therapeutic Jurisprudence, 30 T. JefFerson L. Rev. 455 (2008)). Professor Dickie concluded that "the broader implications of the TJ Model are that forensic psychologists may be able to practice within a legal system that respects an interdisciplinary and psychologically oriented approach to the management of criminal behavior." Dickie, supra, at $460-61$. 
In the same vein, the TJ community needs to focus on the connection between TJ and international human-rights law. ${ }^{275}$ I have called on TJ scholars to immerse themselves in international human-rights law and have listed ten topics on which they might focus their research. ${ }^{276}$ One of these was an investigation of "[t]he TJ implications of instituting reform of forensic facilities." 277 There is an array of scholarship on the relationship between TJ and prisons and other detention facilities, ${ }^{278}$ but there is still perilously little on this topic. This is an area that calls for new investigations and considerations. ${ }^{279}$

All these problems are exacerbated by the pervasive ineffectiveness of counsel in cases involving defendants with mental disabilities in the criminal-justice system. ${ }^{280}$ In an article about the role of counsel in insanity and incompetency cases, I listed multiple issues that, from a TJ perspective, needed additional focus. ${ }^{281}$ Consider this list, and think about the implications of what happens to this population in prison settings where, in some nations, its access to lawyers will be far less than it is even in forensic hospitals: ${ }^{282}$

- If a defendant is, in fact, incompetent to stand trial, that means that he does not have "sufficient present ability to consult with his lawyer with a reasonable degree of rational understanding" and[/]or a "rational as well as

275. For an excellent recent example, see Simon \& Rosenbaum, supra note 80, at 36-41 (discussing the international human-rights implications of involuntary civil commitment policies).

276. For the only important recent exception, see YA'IR Ronen, RE-UndERSTANDING THE CHILD's Right TO IDENTITY: ON BELONGING, RESPONSIVENESS AND Hope (2016) (examining the identity issue through the prisms of TJ and international human-rights law).

277. Michael L. Perlin, "The Ladder of the Law Has No Top and No Bottom": How Therapeutic Jurisprudence Can Give Life to International Human Rights, 37 INT'L J.L. \& PsyChLATRY 535, 542 (2014).

278. See, e.g., Astrid Birgden \& Michael L. Perlin, 'Tolling for the Luckless, the Abandoned and Forsaked': Therapeutic Jurisprudence and International Human Rights Law as Applied to Prisoners and Detainees by Forensic Psychologists, 13 Legal \& Criminological Psychol. 231, 234-35 (2008); Astrid Birgden \& Michael L. Perlin, "Where the Home in the Valley Meets the Damp Dirty Prison": A Human Rights Perspective on Therapeutic Jurisprudence and the Role of Forensic Psychologists in Correctional Settings, 14 AGGRESSION \& Violent Behav. 256, 257 (2009); Dirk van Zyl Smit, Regulation of Prison Conditions, 39 CRIME \& Just. 503 (2010); Cohen \& Dvoskin, supra note 267; Ivan Zinger, Human Rights Compliance and the Role of External Prison Oversight, 48 CAN. J. CRIMINOLOGY \& CRIM. JUST. 127, 127 (2006).

279. I emphatically disbelieve that the retention of the insanity defense and incompetency status will bring about a more humane correctional system. I believe that their abolition will make an inhumane system even more inhumane.

280. See, e.g., Michael L. Perlin, "Too Stubborn to Ever Be Governed by Enforced Insanity": Some Therapeutic Jurisprudence Dilemmas in the Representation of Criminal Defendants in Incompetency and Insanity Cases, 33 Int'L J.L. \& Psychlatry 475, 477-78 (2010) [hereinafter Perlin, TJ Dilemmas]; Perlin, Hidden Prejudice, supra note 177, at 129-34. This criticism, of course, is leveled at practices in the United States. I have worked on every continent and have heard similar stories from advocates in dozens of nations, East and West, North and South.

281. See, e.g., Rebekah Diller \& Emily Savner, Restoring Legal Aid for the Poor: A Call to End Draconian and Wasteful Restrictions, 36 FoRDHAM URB. L.J. 687, 704 (2009) (noting that in many parts of the nation, those in prison have "virtually no access to civil legal representation").

282. See id. 
factual understanding of the proceedings against him;" how can TJ principles be invoked in such a case?

- If a defendant is initially found to be incompetent to stand trial, will the lawyer act as most lawyers and consider him to be de facto incompetent for the entire proceeding (as a significant percentage of lawyers do act for any client who is institutionalized)?

- If a defendant is found to be incompetent to stand trial, will the lawyer assume that he is also guilty of the underlying criminal charge?

- What are the issues that a lawyer must consider in addition to the client's mental state in assessing whether or not to invoke an incompetency determination?

- What are the TJ implications for a case in which the incompetency status is not raised by the defendant, but, rather, by the prosecutor or the judge?

- Are there times when TJ principles might mandate not raising the incompetency status (for example, in a case in which the maximum sentence to which the defendant is exposed is six months in a county workhouse but is in a jurisdiction in which IST defendants are regularly housed in maximum security forensic facilities for far longer periods of time than the maximum to which they could be sentenced)?

- What are the TJ implications of counseling a defendant to plead, or not to plead, the insanity defense?

- Can a defendant who pleads NGRI ever, truly, "take responsibility?"

- Does the fact that the insanity-pleading defendant must concede that he committed the actus reus distort the ongoing lawyer-client relationship?

- To what extent do the ample bodies of case law construing the "ineffective assistance of counsel" standard established by the US Supreme Court in Strickland $v$. Washington ${ }^{283}$ even consider the implications of TJ lawyering?

- To what extent does the pervasiveness of sanism make it obligatory for lawyers in such cases to educate jurors about both sanism and why sanism may be driving their decision-making, and to what extent should lawyers in such cases embark on this educational process using TJ principles? ${ }^{284}$

I believe that $\mathrm{TJ}$ requires a robust and expansive insanity defense. ${ }^{285}$ It demands a reconsideration of policies that punish defendants for raising the defense, reject testimony as to the causal relation between mental disability and the commission of otherwise-criminal acts, and incarcerate "successful" insanity pleaders in maximum-security forensic institutions for far longer than the maximum sentence for the underlying crime, which is often a trivial one. ${ }^{286}$

283. 466 U.S. $668,689-90$ (1984).

284. Perlin, TJ Dilemmas, supra note 280 , at $477-78$.

285. See Perlin, InSANity Defense Jurisprudence, supra note 22, at 417, 419-37 (discussing how TJ can be employed to "make our insanity defense system coherent").

286. TJ is also, in my view, the only option for changing the culture that condones the brutal treatment of mentally ill defendants in prison settings. 
I am convinced, after spending over forty years representing and working closely with persons with serious mental disabilities in the criminal-justice system, that it is the only way that we can begin to eradicate the poison of sanism that contaminates our criminal-justice system.

\section{Conclusion}

The issues that I discuss here have been addressed collaterally over the years, in the context of arguments that seek to abolish involuntary civil commitment. ${ }^{287} \mathrm{I}$ have never embraced those arguments, as appealing as they are on so many levels, because of my fears that a large number of persons now subject to commitment would be arrested and jailed on minor "quality of life" offenses. ${ }^{288}$ Over thirty years ago, in his response to Professor Stephen Morse's then-position that commitment should be abolished, ${ }^{289}$ Andrew Scull wrote that "while Morse may not balk at the prospect of sending the mentally ill to prison, a . . system of justice built around the concept of criminal responsibility almost certainly will."290 I echo Scull's concerns, noting that-given the kinds of charges that are often the subject of incompetency-status inquiries and insanity defenses ${ }^{291}$ - it is inevitable that this population would wind up imprisoned in facilities in which multiple salient articles of the CRPD would be violated, with impunity, on a daily basis, and in which this group of individuals would suffer the wrath of sanism-inspired violence on the part of correctional staff and other prisoners.

In short, I find nothing in the CRPD that requires the abolition of the insanity defense or the incompetency status. Rather, I believe that when that document is read as a whole - side by side with other international human-rights conventions and covenants that require fair trials - it calls out for the retention of these doctrines. The inevitable alternatives - consigning this population to the brutality of prisons-are unspeakable. To return once more to the song lyric with which I began my title, do we seriously believe that, had Abraham followed God's call, he should have been consigned to prison for the rest of his life? In his definitive encyclopedia on Dylan's music, Oliver Trager refers to Highway 61 Revisited as a

287. See, e.g., Stephen J. Morse, A Preference for Liberty: The Case Against Involuntary Commitment of the Mentally Disordered, 70 CALIF. L. REv. 54, 54-57 (1982).

288. See generally Perlin \& Lynch, Interactions with Police, supra note 237.

289. See, e.g., Morse, supra note 287. Morse subsequently modified his position in Stephen J. Morse, Rationality and Responsibility, 74 S. CAL. L. REv. 251, 267 (2000) ("I now believe that involuntary commitment is theoretically justifiable for those whose general capacity for rationality is so impaired that they are not capable of making rational decisions about their lives and not capable of living safely without treatment.").

290. Andrew Scull, The Theory and Practice of Civil Commitment, 82 Mich. L. Rev. 793, 803 (1984). Scull is a prominent historian of psychiatry. See, e.g., Andrew Scull, Madness in Civilization: A Cultural. History of INSANITY, FROM THE BIBLE TO FREUd, FROM THE MADHOUSE TO MODERN MEDICINE (2015).

291. See supra note 164 (noting the proportion of insanity cases that involved death of the victim). 
"scathing, crystalline depiction of a modern-age nightmare." 292 Trager certainly is right about the song, and I believe that this description equally fits any depiction of the treatment of persons with mental disabilities in prison. The disability-rights community cannot, in good conscience, encourage the growth of that nightmare. TJ demands that it be rejected.

292. TraGER, supra note 41 , at 252. 
